\title{
The Excess Land Law: Pressure vs. Principle
}

\author{
Paul S. Taylor* \\ "LATENT CAUSES OF FACTION"1
}

\begin{abstract}
Now I have struck the crux of my appeal [for the excess land law]. I wish to save the very wealthy men of this country and their advocates and upholders from the ruin that they would bring upon themselves if they were permitted to have their way. It is because I am against revolution; it is because I an against the doctrines of the Extremists, of the Socialists; it is because I wish to see this country of ours continued as a genuine democracy; it is because I distrust violence and disbelieve in it; it is because I wish to secure this country against ever seeing a time when the 'have-nots' shall rise against the 'haves'; it is because I wish to secure for our children and our grandchildren and for their children's children the same freedom of opportunity, the same peace and order and justice that we have had in the ..past.-Theodore Roosevelt, $1911^{2}$
\end{abstract}

We talk about political democracy, but we cannot have it without economic democracy. We cannot have political freedom of choice for the individual without economic freedom of choice for the individual. Therefore, I say again today on the floor of the Senate, if I were to be asked to name one thing-if I were limited to the naming of one thing only-which I think is the greatest guarantee of the perpetuity of our democratic form of government, what I would name would be private home ownership in the city and family-farm ownership in the country. On that type of ownership, I think, is dependent, more than we sometimes fully realize, our whole system of political and economic freedom of choice for the individual.-Senator Wayne Morse, $1959^{3}$

The long contest between those who strive to preserve the excess land provisions of federal reclamation law, now in their fifty-eighth year, and those who seek to avoid or destroy them has been rising to a pitch of intensity in California not reached since the middle forties. This issue is the gist of litigation that made its way from the California Supreme Court in 1957 to the United States Supreme Court in $1958{ }^{3 a}$ and now lies again before the Cabifornia Supreme Court in 1959. The issue occupied four days of debate

* Professor of Economics, University of California, Berkeley; consultant to the Office of the Secretary of the Interior and Bureau of Reclamation successively between 1943 and 1952. Elizabeth Dickerson Huttman, Klaus G. Loewald and Beverly Starika assisted in preparation of this paper.

1 The FrDerazist No. 10 (Madison).

2 Theodore Roosevelt, speaking of the excess land law that he inspired personally as President in 1902. 7 Transactions of the Commonwealth Ciub 108 (1912-13).

3105 Cong. Rec. 6894 (daily ed. May 7, 1959).

3a Ivanhoe Irr. Dist. v. McCracken, 357 U.S. 275 (1958), reversing sub nom. Ivanhoe Irr.

Dist. v. All Parties, 47 Cal. 2d 957, 306 P.2d 824 (1957). 
on the floor of the United States Senate, from May fifth to twelfth, 1959. Later the same nonth it entered the legislative debate on the Governor's water program in Sacramento. It permeates negotiations for repayment contracts on Kings River under a disputed administrative order granting immunity from the excess land law to water districts upon discharge of their debt to the Government.

This contest reverberates, in one form or another, in every branch of government-judicial, legislative, and executive-and at every level of government-federal, state and local. It is pervasive because our entire society, like the law, rests on a principle of wide distribution of property. It cuts deeply because the aggregations of landownership that challenge the principle are large, powerful and often geographically concentrated.

The excess land law prescribes that "water shall not be furnished from any [federal] reservoir or dehvered through any such canal or ditch to any one landowner in excess of an amount sufficient to irrigate one hundred and sixty acres." 4 This provision does not affect furnishing water to lands of 160 acres or less in single ownership. Man and wife are entitled to water for 160 acres each. Any landowner within reach of a federal project may obtain water for up to 160 acres, no matter how much land he owns. An owner of more than 160 (or 320) acres of land wishing water to irrigate the excess, may obtain it by agreeing to sell the excess within 10 years at a price appraised to exclude enhanced values resulting from the project; the choice is his. The Supreme Court of the United States has said that

... the claim of discrimination in the 160-acre limitation, we believe ... overlooks the purpose for which the project was designed. The project was designed to benefit people, not land. It is a reasonable classification to limit the amount of project water available to each individual in order that benefits may be distributed in accordance with the greatest good to the greatest number of individuals. The limitation insures that this enormous expenditure will not go in disproportionate share to a few individuals with large land holdings. Moreover, it prevents the use of the federal reclamation service for speculative purposes. ${ }^{5}$

The concentration of ownership of irrigable western lands has concerned Congress from the beginning of federal reclamation and provided the reason for statutory protections against water monopoly, notably the excess land law. As Congressman Oscar W. Underwood, throwing Southern support to Western reclamation, said in 1902:

If this policy is not undertaken now, this great Western desert will ultimately be acquired by individuals and great corporations for the purpose of using it for grazing vast herds of cattle. They will acquire the waterways 
and water rights for the purpose of watering stock and become land barons. Then it will be impossible to ever convert it into homestead lands for our own people or to build up the population of this Western country. I believe the passage of this bill is in the interest of the man who earns his daily bread by his daily toil. It gives him a place where he can go and be free and independent; it gives him an opportunity to be an owner of the soil and to build a home. Those are the class of men we must rely on for the safety of the nation. In times of peace they pay the taxes and maintain the Government; in times of peril and strife they are the bulwark of the nation, and it is justice to them that this legislation be enacted into law. ${ }^{\mathfrak{C}}$

Congressman Underwood was speaking of the family type farm, a tradition that stretches unbroken through American history and spreads across the pages of congressional debate from colonial times to this day.

Throughout its history the concentration of landholdings in California has impeded development of the national family farm pattern in that State. This concentration remains generally characteristic to the present day of the irrigable lands of Central Valley which are the focus of this Article.

In the latest congressional debates, Senator Paul Douglas of Illinois, battling to save the excess land provision in the San Luis, California project bill, cited tables showing that units of 1,000 acres or more comprise 69.8 percent of $1,135,000$ acres in Kern County that include "possible areas of service by irrigation from the San Luis Reservoir south of the Federal service area." A single company owns 16.3 percent of the area. ${ }^{8}$ These ownerships are covered broadly under the current phrase "Kern County interests."

The economic stakes at issue in preservation or destruction of the excess land law are large. Among them are public subsidies that six California Congressmen ${ }^{8}$ have estimated at $\$ 577$ per acre on Central Valley project. Thus the 160-acre excess land law permits an individual to receive public subsidy from Central Valley project in the amount of $\$ 92,320$ (or $\$ 184,640$ for man and wife), but prohibits more.

This Article continues a series analyzing the excess land law and the successive attacks upon the law through the executive, judicial and legis-

635 Conc. Rec. 6672 (1902), remarks of Congressman Underwood.

7 Taylor, Foundations of California Rural Society, 24 CAITF. Hrst. Soc'צ Q. 193 (1945).

8105 Cong. Rec. 6886 (daily ed. May 7, 1959). Earlier statistics of like import appear in Downey, THEY WoULd RULe THE ValleY 164 (1947). Close to three-quarters of a million acres were owned by 34 individuals and corporations in 1947 "in the probable present and future San Joaquin Valley service areas in Central Valley Project (CVP);" none of these loldings were under 5,000 acres.

${ }^{0}$ Letter from Representatives Clair Engle, John Moss, Harlen Hagen, B. F. Sisk and J. J. McFall to Attorney General Edmund G. (Pat) Brown, Feb. 4, 1957, reproduced in 44 CAITF. L. REv. 772 (1957). On San Luis unit, the cost (and, presumably, subsidy) estimates by Senator Douglas are very much higher. 105 CoNg. REc. 6884 (daily ed. May 7, 1959). 
lative branches of government. ${ }^{10}$ It brings the simultaneous pressures in all branches, and at all levels, at the close of the 1950's, into a single focus.

\section{$\mathbf{I}$}

\section{CONGRESS}

The owners of the big estates cannot get what they want by State action alone. They also need Federal help, and they think they can come to Washington, with no one greatly concerned over the issue and push their proposal through Congress on favorable ternis to themselves.-Senator Paul Douglas, $1959^{11}$

As one pauses in this debate to refresh his memory in regard to some of the great scandals in the field of natural resources in our history, and when one thinks of the oil scandals and the oil "steals," the Teapot Dome, the great land frauds, the various types of "steals" of which the powerful economic vested interests of the country have been guilty throughout our history ... let the RECORD show that I think that if our amendment [to retnin the excess land provision at San Luis] is not adopted, the bill will be $a$ water "steal" by the various large landowners the Senator from Illinois has just now listed in the RECORD.-Senator Wayne Morse, $1959^{12}$

I support the 160-acre limitation too.-Senator Clair Engle, $1959^{13}$

Battles over federal water development in California in the 1940's and early 1950's revealed strong opposition by great landowning interests to federal reclamation, because the federal excess land law controls incremental land values and requires ultimate disposal of excess lands. ${ }^{14}$ Plans prepared by the Bureau of Reclamation for a San Luis unit to be added to the Central Valley project were sent to Congress by President Harry S. Truman as early as $1949 .{ }^{15}$ For several years they lay dormant, until a new administration came to power in 1953, ending the New Deal-Fair Deal era and proposing a policy of "partnership" between the federal government and State and local agencies. Simultaneously, Secretary Douglas McKay was offering a relaxed interpretation of the excess land law that held prom-

10 The prior articles by the author are: Excess Land Law on the Kern?, 46 CATr. L. REv. 153 (1958); The Excess Land Law: Legislative Erosion of Public Policy, 30 RockY MT. L. REv. 1 (1958); Destruction of Federal Reclamation Policy? The Ivanhoe Case, 10 STAN. L. REv. 76 (1957); The Excess Land Law: Execution of a Public Policy, 64 Yare L.J. 477 (1955).

11105 Cong. Rec. 6738 (daily ed. May 5, 1959).

12105 Cong. Rec. 6886 (daily ed. May 7, 1959). See also id. at 6895; 105 Cona. Rec. 7056 (daily ed. May 11, 1959).

$13 \mathrm{Id}$. at 7054.

14 See note 10 supra. See also Downey, op. cit. supra note 8. A running fight over public versus private generation and distribution of hydroelectric power generally has paralleled that over the excess land law.

15 U.S. Bureau of Reelamation, Dep't of the Interior, Cientral. Valley Basin Report, S. Doc. No. 113, 81st Cong., 1st Sess. 129-30 (1949). 
ise of easy avoidance. ${ }^{16}$ In this atmosphere, both friends and opponents of the excess land law came before Congress in 1955 and 1956 to discuss further federal water development in Central Valley. ${ }^{17}$ Even these hearings held by the Senate on the San Luis unit developed little agreement on what should be the nature of partnership on the project, or indeed, whether there should be any partnership at all. The testimony of two important witnesses before the Senate committee illustrates the disagreement:

Master of the California Grange, George Sehlmeyer, favored federal construction partly as a means of preserving the excess land law, and opposed State construction, partly at least, because he feared that State construction would be used to circumvent the law. Asked whether "one of the reasons why the State is moving in [to supplement or replace federal development] is to get rid of the land limitation?" he replied, "I think that was an important factor ...."18

A California assemblyman from Kern County, Patrick Kelly, favored State development as strongly as the Grange master favored federal construction. He said, "As an inherent part of the development of its natural resources under the sovereignty of the State of California, it is suggested that the management and control of all of the elements of the Cahiforma State water plan, including the San Luis unit thereof, should be vested primarily with the State of Califorma." "19 The hearmgs failed to produce a committee report.

Similar differences over policy appeared at Senate hearings 2 years later, in 1958. On one hand, the California State Federation of Labor insisted on construction of San Luis project "under reclamation law without deviation or evasion" and protested against any attempt to persuade Congress to relieve the State of California from the obligation required of all to observe the excess land law when using federal facilities. ${ }^{20}$

On the other hand, a member of the Kern County Water Commission and chairman of the Water Problems Department of the Kern County Farm Bureau presented a resolution of the California Farm Bureau Feder-

\footnotetext{
16 See infra, text at note 92 .

${ }^{17}$ Hearings on S. 178 Before the Irrigation and Reclamation Subcommittee of the Senate Committee on Interior and Insular Affairs, 84th Cong., 2d Sess. 1 (1956).

$18 \mathrm{Id}$. at 175-78. (Emphasis added.) The other factor, he said, was to avoid federal "power" policy.

$18 I d$. at 252 . (Emphasis added.)

20 Testimony of C. J. Haggerty, secretary-treasurer, Cahifornia State Federation of Lahor, Hearings on S.1887 Before the Irrigation and Reclamation Subcommittee of the Senate Committee on Interior and Insular Affairs, 85th Cong., 2d Sess. 185-86 (1958) [hereinafter cited as 1958 Hearings on S. 1887]. See also Hearings on S. 1425, S. 2541 and S. 3448 Before the Irrigation and Reclamation Subcommittee of the Senate Committee on Interior and Insular Affairs, 85th Cong., 2d Sess. 155-59 (1958) [hereinafter cited as 1958 Hearings on S.1425, S.2541 \& S. 3448].
} 
ation declaring that "cooperation should be only on the basis of control of the projects and properties by the State of California." He recommended construction by the State, and agreed that if the Senate coinmittee did "not take the Kern County amendments ... the California Farm Bureau Federation ... could not approve and support the bill." Summarizing, he said:

Fundamentally, it is our position that any ... authorizing legislation, and any agreement thereunder, shall recognize the right of the State to construct, operate, and control the mainline facilities of the State project; and that the State shall exercise control with respect to determination and administration of the right to the use of water. ${ }^{21}$

California has had no general legislation providing subsidies to irrigation nor any excess land provision. ${ }^{22}$ Federal financing, on the contrary, is very generous under reclamation, and carries an excess land provision. When federal subsidies are spurned by local interests, it is for special reasons. Unmistakably the real bone of contention over San Luis project was the excess land law, and the desire to enforce or avoid it influenced the choice between federal and State projects, and when the choice was made, raised the question which law should govern them into an issue.

The bill, S. 1887, which reached the Senate floor in the 85th Congress was a coinpromise. It provided for federal construction and offered the benefits of federal financing to all interests in California. It offered to its friends the application of the excess land law to one area to be served by the federal project; it offered to its opponents the exemption of waters flowing to another area, outside the federal project. ${ }^{23}$

The principal instrument of exemption, inserted apparently in response to the views from Kern County interests, was an amendment added by the Senate committee just as the bill reached the floor on August 15, 1958. By this procedure, the legislation proposed on the most controversial issue escaped some of the attention it would have drawn if made public earlier. The amendment read, in part:

Sec. 7. The provisions of the Federal reclamation laws shall not be applicable to water deliveries or to the use of drainage facilities serving lands under contract with the State to receive a water supply, outside of the San Luis service area . . . 24

Senators Douglas and Morse tried on the Senate floor to strike out section 7 together with a clause applying the excess land law except when "inconsistent with this act." California Senators demanded retention of

21 Testimony of Allen Bottorff, 1958 Hearings on S. 1887, at 101-09. (Emphasis added.)

22 Financing the water program enacted in June 1959 depends on popular approval of a bond issue in 1960. San Francisco Chronicle, June 23, 1959, p. 34, col. 1.

23104 Cong. REc. 17723-35 (1958).

24 Id. at 17724. 
section 7 as necessary protection to their State from what they called federal imposition. They minimized discussion of excess lands. When Senator Morse inquired of Senator Kuchel as to the "present pattern of landownership" and "size of the land holdings" in the area to be exempted from the excess land law-an area known generally and from public records to consist of vast landholdings-the latter replied: "It is not known to me ..." and changed the subject to a prospective State water program. ${ }^{25}$

Senators Douglas and Morse failed to preserve the excess land law. The Senators from California, with active help from Senator Clinton P. Anderson, chairman of the Senate committee, overrode Senators Douglas and Morse to secure Senate passage of the bill with the exemptions from reclamation law desired by spokesmen for Kern County interests. The House, however, failed to act, so the bill died with the expiration of the 85th Congress.

A revised San Luis bill, S. 44, was prepared in the 86th Congress and presented originally in identical form to both Houses. Essentially it represented the same compromise embodied previously in S. 1887 of the preceding session. The section carrying the exemption passed in preceding session had been omitted from the original draft submitted to the 86th Congress by "inadvertence," as Senator Kuchel explained. ${ }^{26}$ It was restored, and proved again to be the main issue in the Senate.

This time the outcome of debate on the floor of the Senate was precisely the reverse of the outcome in August, 1958. After 4 days of debate conducted mainly by Senators Kuchel and Engle of California on one side, and Senators Douglas of Illinois and Morse of Oregon on the other, the Senate eliminated the identical exemption from the excess land law it had approved 9 months earlier. ${ }^{27}$

${ }^{25}$ Id. at 17733. Extensive data on size and pattern of landholding appear, for example, in Hearings on S.912 Before a Subcommittee of the Senate Committee on Public Lands, 80th Cong., 1st Sess. 861 (1947); 1958 Hearings on S.1425, S. 2541 \& S.3448, at 181.

26105 Cong. Rec. 6726 (daily ed. May 5, 1959).

${ }^{2 \tau}$ It is not entirely clear whether Senators Kuchel and Engle were equally devoted to the particular means of removing the excess land limitation represented by $\S 6(a), S .44$ ( $\$ 7$, S. 1887, 85th Cong., 2d Sess. (1958)). During the debate in the 86th Congress Senator Morse said: "The junior Senator from California, in my judgment, has never gone as far as the senior Senator from California has gone in respect to section 6(a). He has left me with the impression that he would be perfectly willing to have section $6(\mathrm{a})$ come out of the bill, because he does not believe it makes any difference whether it stays in or comes out. Of course, the junior Senator fron California is in a position that many of us find ourselves in from time to time. He would like to go along with his colleague, because his colleague, the senior Senator from Cahifornia, happens to be the leader in the fight for section $6(a)$, and therefore the jumior Senator is not advocating deleting section 6(a). But certainly he has made it clear in the debate that he has no objection if it comes out. In other words, he is not insisting that it stay in." Senator Engle replied, "The distinguished Senator from Oregon has represented my position correctly." 105 CoNg. Rec. 7168 (daily ed. May 12, 1959). At another point, Senator Engle said, "I want to make a record which is very plain indeed that in my opinion the section is 
Congressional hearings and debate reveal the complexities of the excess land problem that tend to obscure a simple principle, and that have led even specialists almost to despair. ${ }^{28}$ To follow the course of the San Luis bills of 1959 through Congress is an exercise im clarification.

The San Luis bills were drawn and presented on an assumption that there were to be two projects, represented by water deliveries to a "Federal service area," and to a "State service area," respectively. Some of the facilities, however, including a reservoir, canal, and pumping plant were designated as "joint-use facilities." The State of California was expected to make financial contributions toward the cost of construction and to share the use of federal facilities to transfer water from northern sources to southern areas of delivery. ${ }^{29}$

The argument for an exemption from the excess land law, led on the floor of the Senate by Senators Kuchel and Engle, comprised four main points: (1) The State project is separate, except for joint use of certain facilities, from the federal projects; (2) federal law should not be imposed on the State project; (3) any policy governing clistribution of water and benefits from the State projects should be left to the State to decide; and (4) everyone (or nearly everyone) interested in the project is agreed upon the bill.

(1) Senator Kuchel stated the first point in these words:

[T]wo systems-one a Federal project in being; the other, a State project about to get underway-would both be served at San Luis, the point where they cross, by a single storage reservoir whose cost of construction and operation would be shared by both governments. ${ }^{30}$

surplusage. It is merely a statement of what the law is." To Senator Douglas' demand, "If it is surplusage, then eliminate it," Senator Engle replied, "The people affected want this additional assurance." 105 CoNG. REc. 6738 (daily ed. May 5, 1959). The identity of the interests affected is discussed infra, text at note 178. Senator Richard Neuberger of Oregon, a member of the Senate committee that had approved S. 44, joined Senators Douglas and Morse. See id. at $6734 ; 105$ Cong. Rec. 7172 (daily ed. May 12, 1959).

28 In speaking of the San Luis bill in the 85th Congress, Senator Clinton P. Anderson, chairman of the subcommittee, said: "You understand that a person who is not a lawyer, and I am not a lawyer, has a great deal of difficulty following all these things. I try my best to find what is in it that strikes down the limitation. I cannot find it." 1958 Hearings on S. 1425, $S .2541 \& S .3448$, at 159.

29 See S. 44, H.R. 301, H.R. 5687 and H.R. 7155, 86th Cong., 1st Sess. (1959).

30105 Cong. Rec. 6725 (daily ed. May 5, 1959). See also 105 Cong. Rec. 6888 (daily ed. May 7, 1959); 104 Cowe. Rec. 17731 (1958).

Whether one, several, or many federal facilities are desired for eventual use as part of the State project is not wholly clear. The 1956 State Water Plan regards Folsom Reservoir on the American River, constructed by the federal government and an integral part of Central Valley, as part of the State project for delivering water from northern sources to areas south of San Luis: "These large foothill reservoirs, including Folsom, are considered to be features of the California Aqueduct system but will also serve some local purposes." See 2 CaL. Water Resources Bd., Bulc. No. 3, Report on the California Water Plas 9-239 (preliminary ed. 1956). 
If the State system were physically separate from the federal system, of course federal law would not apply to the State system, but it was not separate. The fact that it was not separate became crucial. As Senator Kuchel acknowledged with evident regret, "If there were two reservoir sites, and if the State developed one reservoir site and the federal government developed the second reservoir site, so there would be two parallel systems, each with a storage reservoir, there would be no problem."31 But since the projects were joined, Senators Kuchel and Engle were obliged to ask for an exemption from federal law, and in order to support their request, to try to create an image of separation in which the physical fact of joint-use would be minimized or overlooked. Senator Engle tried to do this by describing the supposed financial separation of State and federal systems. He argued:

[T] here will not be a plugged nickel of Federal money in the State project, and everything the State does in order to put a bucketful of water on a square foot of land will be paid for with State money. That is the reason why we have a provision in the bill that the Reclamation law shall not apply to a wholly divisible, completely separate program that is paid for, lock, stock, and barrel-powerhouse and all-by the State taxpayers. . . . All the Federal Government has done has been to build the first story of the structure. The second story goes on at no cost to the Federal Government. ... The State governunent will pay every nickel of its share. Not a penny of it will be charged to the Federal taxpayers. . . The projects are completely severable. They do not overlap or intermix. ${ }^{32}$

A few days later Senator Engle, in pressing his argument again, spoke of "projects built by the State government, projects for which the State has paid every cent. ${ }^{33 "}$ To this, Senator Douglas replied:

Previously, they have been saying this would be a 100 percent State project. But it turns out to be nothing of the sort. A large part of the basic cost of the Oroville project is to be charged to the Federal government, in the case of the flood control, and possibly navigation costs; and only the residue, or the irrigation costs, are to be borne by the State government. And as I shall shortly suggest, perhaps even some of these irrigation costs of the so-called State project will also be thrust on the Federal government .... This shows what an illusion it is to call this a separate State project . . . .

Senator Engle volunteered that he had sponsored the law authorizing a federal nonreimbursable flood control contribution to the State project,

31105 Cong. REc. 7071 (daily ed. May 11, 1959). See also Senator Morse's remark: "If there is a case of solely State waters, of course it does not apply; that is up to the State legislature to determine." Id. at 7074; 105 Cong. REc. 7168 (daily ed. May 12, 1959).

32105 Cong. Rec. 6731, 6732 (daily ed. May 5, 1959). Senator Douglas remarked during this colloquy that it would be "impossible to have a second story without the federal expenditures on the foundation and the first story."

33105 Cong. Rec. 7056 (daily ed. May 11, 1959).

34 Id. at 7057,7058 . 
and was "proud" of it. ${ }^{35}$ Senator Douglas inserted in the Record a page and a half of material that Senator Engle bad inserted in the Record as Congressman in 1957, proposing that the federal government should make interest-free contributions to the State project as well. ${ }^{36}$ The Engle proposal of 1957 , if adopted, would have preserved the generosity of federal reclamation law to the State and dispensed with policy.

(2) Senator Kuchel, directing his remarks toward Senator Frank J. Lausche of Ohio, who had joined debate on the side of Senators Douglas and Morse, stated the second point in his and Senator Engle's argument for an exemption from the excess land law:

We believe that when one reservoir is jointly used by the State and by the Federal Government it is unconstitutional for the Federal Government to tell the State of the Senator from Ohio or my State how it shall use its water in a State system, when the water comes from that system. ${ }^{37}$

This argument resembles one used by former Senator Sheridan Downey to support the Elliot-rider exemption of Central Valley project from the excess land law in 1944, which Senator Carl Hatch of New Mexico disposed of in these words:

[T] he Senator from California has said here on the floor that officials of the Reclamation Service are trying to straitjacket the people of California. The people of California came to the Congress of the United States and obtained the appropriations under the reclamation laws. No one here is trying to do anything to Califormia. ${ }^{38}$

No proposal was before the Senate in 1959 to impose federal law upon a California State project. The language of section $6(a)$ showed on its face that this was not the issue:

The provisions of the Federal reclamation laws shall not be applicable to water deliveries or to the use of drainage facilities serving lands under contract with the State to receive a water supply, outside of the Federal San Luis unit service area described in the report of the Department of the Interior, entitled "San Luis Unit, Central Valley Project," dated December $17,1956.39$

Senators Douglas and Morse made it clear that the only issue before the Senate was whether an area in California should be made an exception to existing reclamation law.

The Warren Act of 1911, whose terms section 6(a) would breach

35 Id. at 7057.

36 Id. at $7058,7059$.

37105 Cong. Rec. 6888 (daily ed. May 7, 1959).

3890 CoNG. Rec. 9499 (1944).

${ }^{39}$ S. 44, 86th Cong., 1st Sess. § 6(a) (1959). (Emphasis added.) See 105 Covg. REc. 6729 (daily ed. May 5, 1959). 
specifically, was designed to provide the basis for cooperation in reclamation between the federal government and other agencies, public and private, corporate and individual. Federal cooperation was offered on the basis of compliance with federal policy, i.e., that "water shall not be furnished from any sucl reservoir or delivered through any such canal or ditch to any one landowner in excess of an amount sufficient to irrigate one hundred and sixty acres. ..."40

(3) The third point in the argument of Senators Kuchel and Engle was that authority to determine policy on the State project belonged, and should be left, to the State. Senator Kuchel said the bill "slıould unequivocably declare that Federal laws will not in any way or manner affect lands which may be supplied from features which are a part of the California water plan." He demanded that "the water for storage in this reservoir which is to be used by the State of California in the State system, paid for by the people of California, and almost conipletely to be used for domestic purposes, shall be governed by the law of the State of California, and by the law of the State of California alone." 41

Senator Douglas, rejecting Senator Kuchel's view, including his opinion that the State water would be "almost completely for 'doniestic' use," said:

The State of California has no acreage himitation law... . We can be certain that if and when water is put on the second block of land, it will be put on land owned by the large landholders. ${ }^{42}$

[I]f the State wants to adopt its own acreage limitation, that will be fine. Let the State do so first, however, and then let it come back to us. Let us not destroy the federal land policy now, before the State acts, on the basis of hope. ${ }^{43}$

He was not optimistic that the California Legislature would pass a limitation:

Since it was not possible to pass any legislation there upholding the 160 acre limitation in the past, I cannot believe that the California Legislature, much as it has improved, will pass such a law in the future. ${ }^{44}$

Senator Engle suggested a more favorable prospect in the State legislature, by introducing a telegram from Governor Edmund G. Brown of California, giving support to Senator Kuchel and himself in the view that policy in the State service areas "should come as a result of State legislation." Governor Brown said: "I intend, at an appropriate time and before contracts are executed, to take this matter up with the California Legis-

${ }^{40}$ Warren Act, 36 Stat. 925, 926 (1911), 43 U.S.C. § 523 (1952).

41105 Cong. Rec. 6726 (daily ed. May 5, 1959).

42105 Cong. Rec. 7165 (daily ed. May 12, 1959).

43 105 Cong. Rec. 706I (daily ed. May 11, 1959). See also id. at 7076.

44105 Conc. Rec. 6890 (daily ed. May 7, 1959). 
lature in order to preclude the undesirable results which I have described ..." and expressed his belief "that the California Legislature ... is . . . opposed to any unjust enrichment or monopolization of benefits by owners of large landholdings as a result of either Federal or State operation. ${ }^{\text {.40 }}$

Senator Douglas observed that "it is one thing for the Governor to propose such a program, and it is quite another thing for California to enact such a law. Until California comes forward with a law at least as good as the Federal law, I do not believe we should give up the protection the Federal law affords." ${ }^{46}$

(4) Senator Kuchel presented the bill as a measure bearing united approval, federal and State, legislative and executive, Republican and Democrat, and endorsed by past and present officials. Besides himself, a Republican, and Senator Engle, his Democratic colleague, he included among those who had approved the bill the Republican Secretary of the Interior, the Democratic Governor of California, and former Governor, Goodwin J. Knight, a Republican. ${ }^{47}$ At another point he included the name of former Democratic Senator Sheridan Downey as further evidence of bi-partisan support for his position. ${ }^{48}$

Senators Neuberger, Morse, and Douglas inserted evidence in the Record that groups and individuals in California supported them in their opposition to alteration of the excess land law, as proposed by Senators Kuchel and Engle. Among these were statements from the California Labor Federation, ${ }^{49}$ Grange, ${ }^{50}$ Water and Power Users Association, ${ }^{61}$ Young Democrats, ${ }^{52}$ Democratic Council,${ }^{53}$ party officials, ${ }^{54}$ clubs and individuals. ${ }^{55}$

\section{Ibid.}

46105 Cong. Rec. 7069 (daily ed. May 11, 1959). See infri, text at notes 77-79, reciting the rejections of acreage-limitiation proposals by the California Legislature both prior and subsequent to these debates in the United States Senate.

47105 Cong. Rec. 6725 (daily ed. May 5, 1959).

48105 Conc. Rec. 7162 (daily ed. May 12, 1959). It is generally believed in California that one of the main reasons Senator Downey did not run for re-election to the Senate in 1950 was the opposition le aroused by persistent efforts to remove the excess land limitation governing the Central Valley project. See remarks of Senator Douglas, 105 Cong. Rec. 7069 (daily ed. May 11, 1959).

49105 Cong. Rec. 6735 (daily ed. May 5, 1959); 105 Cong. Rec. 7054-55 (daily ed. May 11, 1959).

50 Id. at $7053,7079$.

51 Id. at 7079.

52105 Cong. Rec. 6735 (daily ed. May 5, 1959); 105 Cong. Rec. 7052 (daily ed. May 11, 1959).

53 Ibid.

54 Id. at $7052,7078$.

65105 Cgnc. Rec. 6735 (daily ed. May 5, 1959); 105 Cong. Rec. 7165, 7169 (daily ed. May 12, 1959). See also 105 Conc. Rec. 6889 (daily ed. May 7, 1959); 105 Conc. Rec. 7053, 7062, 7063, 7073 (daily ed. May 11, 1959). 
Sponsors of removal of the excess land provision from the area to be served with waters of the State system using federal facilities avoided discussion of the great concentration of landownership there. On this, the very substance of the issue, Senators Kuchel and Engle tended to be evasive or silent..$^{\text {s6 }}$

Senators Douglas and Morse, on the contrary, spread the facts regarding extreme concentration of ownership extensively on the Record, and appealed strongly to the Senate to preserve national policy as a support to democratic institutions and popular government. ${ }^{57}$ Senator Douglas said:

The power of those holding the land will be enormously increased. ${ }^{58}$... The American system is that the person who farms the land should, insofar as possible, be the farm owner. That is the basis on which democracy was established in the Mississippi Valley; but that basis of agrarian democracy does not exist in large areas of California. ${ }^{59}$

Senator Douglas appealed to the California Senators "not to come into this Chamber shackled with the chains of the Southern Pacific Land Co., the Boston Ranch Co., the Kern County Land Co., the Standard Oil Co., the other oil companies, and other large landowners ...,",00 and offered to debate the issue with them in California ${ }^{61}$ He summarized the case for preservation of the excess land law in these words:

What is it in the Federal reclamation law that the two Senators from California want to avoid? They say they do not want the Federal reclamation law to apply in this 500,000-acre block of land-of course they never tell us precisely where or how much it is-which will be brought in after the initial 440,000 acres are.

66105 Cong. Rec. 6889 (daily ed. May 7, 1959); 105 Cong. Rec. 6733 (daily ed. May 5, 1959). At one point in the debate Senator Kuchel stated that the people who wanted the exemption and who would be "affected" by it were not "the big landowners of the Central Valley," but "the city government of the city of Los Angeles." Id. at 6738. The excess land law applies to irrigation for agriculture, not to the domestic or industrial uses of water which are given as the chief interests of Southern California. Nevertheless, statements were inade in the name of the Metropolitan Water District of Southern California insisting on the language of $\S 6$ (a) "to increase the confidence of our people" in view of the "confusion" over applicability of federal and State laws, and also in the name of the Los Angeles Chamber of Commerce "for protection against Federal dommation in State water matters." Hearings on $H R .301, H . R .302$, $H . R .5681, H . R .5682, H R .5684$, and $H . R .5687$ Before the Irrigation and Reclamation Subcommittee of the House Committee on Interior and Insular Affairs, 86th Cong., 1st Sess. 98-99 (1959); Hearing on S. 44 Before the Irrigation and Reclamation Subcommittee of the Senate Committee on Interior and Insular Affairs, 86th Cong., 1st Sess. 94-95 (1959).

67105 Conc. REc. 6732, 6733, 6738 (daily ed. May 5, 1959).

68 Id. at 6737, 6739. See also 105 Cong. Rec. 7164 (daily ed. May 12, 1959).

60105 Cong. Rec. 7058 (daily ed. May 11, 1959).

${ }^{60}$ Id. at 7062. See also 105 Cong. Rec. 6885 (daily ed. May 7, 1959); 105 Cong. Rev. 7166 (daily ed. May 12, 1959).

61105 CoNg. Rec. 7071 (daily ed. May 11, 1959); 105 Cong. Rec. 6889 (daily ed. May 7, 1959). Senator Douglas said: "I hope the Democratic Party of California does not come out in defense of the large landowners." Ibid. 
Why? There is only one answer-because they do not want the 160-acre limitation to apply. The Senators will not come out openly and say that, but that is the reason.

There is no question of States' rights involved. As a matter of fact, we know California does not have any law on this subject at present.

Knocking out section 6 (a) would not replace the Federal reclamation law with a State law. A vacuum would be left.... We do not want a vacuum in the law, because into that vacuum will rush the big landowners with their possession of tens of thousands of acres, in some cases over a hundred thousand acres so that they will get an increase in the value of their land, to the extent of $\$ 600$ an acre, on an average, which will mean enormous benefits. From whom? These benefits will come from the taxpayers of the country as a whole.

In this process the entire irrigation and reclamation program of the country will be so besmeared and discredited that an indignant public will repudiate the whole thing. ${ }^{62}$

The debate ran on during 4 days, until the Douglas-Morse-Neuberger amendment to preserve reclamation law won by a division. ${ }^{62 a}$ Senator Douglas warned that "if section 6(a) comes back into the bill, I believe it will be found that the Senator from Illinois, the Senators from Oregon, and other Senators will be quite vigorous in their opposition." the House committee, with six members dissenting, retained the section the Senate had eliminated. ${ }^{\text {st }}$

62105 Cong. Rec. 7076 (daily ed. May 11, 1959).

62a 105 Cong. Rec. 7170 (daily ed. May 12, 1959).

$63 \mathrm{Id}$. at 7175 .

64 H.R. REP. No. 399, 86th Cong., 1st Sess. 25 (1959). The disputed provision of the House bill was $\S 7$ of H.R. 7155. Congressman B. F. Sisk, author of the San Luis bill in the House, announced in July that he would not seek action before the 1960 session. This decision was reached in consultation with the two Senators and the Governor of California, the House leaderslip and chairmen of the Interior and Irrigation and Reclamation Committee and Subcommittee, respectively. Congressman Sisk expressed "regret" over the "five months delay," but called delay the "best strategy to insure the earliest actual construction of the project which is so important to the San Joaquin Valley and to the success of the California Water Plan." In explanation he said: "It is not easy to secure approval of any federal reclamation proposal. Because of its size, San Luis naturally will be the subject of extensive debate and the time of its presentation is important." Fresno Bee, July 31, 1959, p. 4-A. He said it "would be difficult to advance" the bill "with other major legislation still pending as Congress moves toward adjournment." San Francisco Chronicle, Aug. 1, 1959, p.4, cols. 3, 4. In May, Senator Lausche liad pointed out specifically that "there are Senators who would vote for the bill" provided it preserved national policy. 105 Cong. Rec. 6890 (daily ed. Mray 7, 1959). After Senate decision to preserve policy, the project carried easily by voice vote. Dissent from the House report was grounded, not on opposition to the project, but on unwillingness to accept the insistence of the majority, including the author of the bill, on rejection of the Senate decision to preserve national policy. 
$[N]$ o one would believe that shrewd, calculating business men would invest their money on the strength of land rising in value while unimproved, for even the farmer himself has to abandon it who endeavors to add to its value without water. At the same time, purchasers are not lacking who would add it to their already extensive dry domain and the people, in the next legislature, will find themselves confronted by an array of force and talent to secure to capital the ownership of the water as well as of the land, and the people will at last have it to pay for. . . - Visalia Delta, May 5, 187765

At one stage in the bitter debate, Assemblyman Jesse M. Unruh (DemLos Angeles) declared, "At times we have to rise above principle." He had been twitted by Assemblyman Lloyd W. Lowrey (Dem-Rumsey) for opposing the latter's water acreage amendment which is part of both the State and national Democratic platforms. - Earl C. Belırens, $1959^{66}$

Congress and State legislature play correlative and changing roles in California water development. "Partnership" began, in the limited sense of a creditor-debtor relationship, when federal reclamation started to pour funds into the State, and the legislature, in order to facilitate receiving them, authorized State water districts to enter into repayment contracts in compliance with federal reclamation law. ${ }^{67}$ The Central Valley Project Act of 1933, approved by legislature and voters alike, gave the State Water Project Authority the "full power to do any and all things necessary in order to avail itself of such [federal] aid, assistance and cooperation under Federal legislation now or hereafter enacted by Congress." ${ }^{68}$ On May 26, 1936, the State senate and assembly memorialized Congress in identical resolutions to make continuing appropriations to assure completion of the Central Valley project which President Franklin D. Roosevelt had made "reimbursable in accordance with the Reclamation Law."

No one in California, apparently, ever has dissented from the general and officially expressed desire to encourage the flow of federal funds into the State for water development. Attitudes toward federal policy for distributing water and preventing speculative gain, lowever, have differed sharply. As early as 1937, Kern County interests sought ways of obtaining

65 Page 2, col. 3.

BB San Francisco Chronicle, June 18, 1959, p.15, col.1.

67 CaI. WATER Code $\$ \S 23175-302$. These sections were first enacted in 1917. Cal. Stat. 1917, c. 562. The first federal reclamation project in California was begun before World War I at Orland, in the Sacramento Valley; a 40-acre water limitation was applied.

68 Cat. Water Code $\$ 11500$. (Emphasis added.)

69 Cac. Senate JouR., Extraord. Sess. 13-14, 35-36 (1936). 
federal aid and at the same time avoiding the excess land law, whether through admimistrators ${ }^{70}$ or through Congress. ${ }^{71}$

Use of the State of California for this purpose was attempted about 1944 in the form of a proposal that it should purchase Central Valley project from the federal government. ${ }^{72}$ State purchase of Central Valley project suffered from the disadvantage in winning popular support that it proposed substitution of State for federal funds for past construction. ${ }^{78}$ More recently a State Feather River project, proposing use of State funds for future construction has proved more attractive. Yet efforts have proceeded in the face of great resistance and, very slowly, to obtain, successively, legislative authorization of a State Feather River project in 1951,74 an appropriation of $\$ 25,190,000$ for acquisition of land and relocation of highway in $1957,7^{75}$ and an appropriation to begin construction in $1959 .{ }^{70}$

In 1957 an amendment to incorporate an excess land provision in the Feather River Project bill was tabled in the assembly without debate by vote of 46 to 25 . Assemblyman Francis C. Lindsay, author of the bill, opposed the amendment on the ground that it was not the time to raise questions of policy. He "urged the legislators to defer policy arguments about power and other matters until their spring session and concentrate during this short January meeting on a simple form of appropriation, merely providing the money asked by Governor Goodwin J. Knight. ..." The legislature acted similarly in 1959. As if to validate Senator

70 Testimony of Roland Curran, secretary-manager, Central Valley Project Association, Hearings on S. 912 Before a Subcomnittee of the Senate Committee on Public Lands, 80th Cong., 1st Sess. 1310 (1947). For an account of even earlier objections to the excess land law, see testimony of Secretary of the Interior J. A. Krug, id. at 991.

71 The possibility that Congress might rebuff them appeared early. See Hearings on H.R. 3961 Before a Subcommittee of the Senate Committee on Commerce, 78th Cong., 2d Scss. 529-788 (1944).

72 This "proposal, said to have originated among the big lanclowners of Fresno County, is for the State of California to take over the Central Valley project, paying the entire bill, This, too, would sidestep the 160-acre limitation." Business Week, May 13, 1944, p. 24. See also Bureau of Public Admmistration, Untverstty of Cax., Centrai Vatley Project: Federat. OR STATE? (May, 1955) (report prepared by Hugh G. Harisen, for the bureau, for California Assembly Interim Cominittee on Conservation, Planning and Public Works, pursuant to House Resolution No. 177, 1953). About the same time the California Legislature memorialized Congress by joint resolution to pass the Elliot rider exempting Central Valley project from the excess land law. Cal. Stat. 1945, c. 24, p. 285.

73 Senator Morse: "Various State takeover proposals were made. These fell because they were far too big a chunk for California's taxpayers to swallow:" 105 CoNG. REc. 7166 (daily ed. May 12, 1959).

74 Cal. Stat. 1951, c. 1441, § 2.

75 Cal. Stat. 1957, c. 15, § 1.

76 Oakland Tribune, June 21,1959 , p. 1, col. 2 .

77 Sacramento Bee, January 23, 1957, p. A-6, col.2. Public policy amendments, sponsored by Assemblyman Lloyd Lowrey, who sponsored the excess land amendment, failed of passage twice in eight hours. 1 Cax. Assearbex Jour., Reg. Sess. 808, 809 (1957). 
Douglas' prophecy early in May in Washington, that the California Legislature would not approve excess land legislation, the State senate defeated an excess land amendment to Governor Brown's water program bill on May 29th. Its sponsor, State Senator Virgil O'Sullivan, argued that without a State acreage limitation " we are going to make a few millionaires and add to the millions some already have." "Leading the fight for the Governor's bill, Senator Hugh M. Burns told the State senate this was " 'neither the time nor the legislation" " in which to deal with acreage limitation, and the amendment was defeated, 25 to $10 .{ }^{78}$

The assembly also dechned to approve excess land (and public power preference) proposals. Assemblyman John A. O'Connell "contended the legislature should decide the issues before the state votes on the proposed $\$ 1,750,000,000$ bond issue . . ." The Assembly Water Committee, however, referred both bills for "interim study." Th Thus the 1959 session of the legislature ended with passage of a proposal, silent on policy, asking the people to finance State water projects by a bond issue.

Congressional procedure usually is to pass an authorization bill first, declaring policy. Appropriations to finance construction of the authorized project are considered afterwards. Congress followed this customary procedure in passing the National Reclamation Act of 1902, which was an authorization bill. It could not have passed Congress except for the inclusion of an excess land policy. The debates show this, and it has been attested to by a competent witness, John E. Raker, judge and later Congressman. He said in 1905: "The committee of seventeen [western members of Congress] that originally planned and arranged the adoption of the National Irrigation Law secured its adoption and presentation to Congress solely and entirely upon the question that the great land monopolies in the United States would be prohibited from getting the benefit of it." ${ }^{280}$

When the State of California planned its first great State water project in 1933, the legislature joined policy to finance in the bond issue for $\$ 170,000,000$ that it submitted to the voters for a State Central Valley project. ${ }^{81}$ The successful campaign for passage of the referendum relied heavily on its policy provisions to win support for the bond issue. ${ }^{82}$

78 Sacramento Bee, May 30, 1959, p. A-6, col. 1. A public power preference amendment also sponsored by State Senator O'Sullivan was defeated by 21 to 16 .

79 Sacramento Bee, June 3, 1959, p. A-10, col. 5. (Emphasis added.)

80 Proceentings, Thurteenth Nationat Irrigation Congress (Portland, Oregon) 61, (1905)

81 CaI. Water CoDE $\S \S 11464,11500$. This policy, in this instance, was public power preference; excess land policy had not been raised as an issue at that time, but see supra, note 68 .

82 Cat. Legislative Counsel, Referendum Measure to be SubMttited to the Eiectors of tare State of Carifordia at Spectat Euection to be Held TUesdax, Dec. 19, 1933 (voters' guide, distributed by Cal. Secretary of State), on file in Bureau of Public Administration Library, University of California, Berkeley. 
Governor Brown, however, rejected this procedure in 1959, by opposing inclusion of policy in his bond issue measure. When the legislature followed the Governor's recommendation by defeating policy in the State senate, Governor Brown approved: "Some of the principles (in the amendments) are sound," he said, "but they don't belong in bond legislation designed to provide financing, not to settle every water argument in the state." 83

Just after the legislature passed the water bill, a leading California newspaper that had supported the Governor's program said that action on policy should come earlier than had been planned. It said editorially that, among other matters, acreage limitation "ought to be resolved before the voters are asked to pass on the bond issue." "The California Labor Federation, too, pressed for early action. It supported its request by a political warning: "If the Governor fails to propose, or is unsuccessful in securing anti-enrichment protections, he may go down as the Democratic Governor who put California in the water and power business for the enrichment of landed monopolists rather than the people of the State of California." 85

The absence of policy from the bond issue might be sufficient to defeat it, since people like to know the purpose for which they spend money. So far as concerns excess land policy, a few weelss earlier Senator Morse had raised a question whether "This evanescent project, . . . this alleged State project we are dealing with . . . is merely a vision created in the hope that it can somehow transform everybody's water to water reserved only for a few people." ${ }^{\text {86 }}$

The passage of the Governor's water program by the legislature advanced the prospects for State water projects, but these remained exposed to objections on niany and diverse grounds, and uncertain. ${ }^{87}$ The

83 Sacramento Bee, May 30, 1959, p. A-6, col. 1.

84 Sacramento Bee, June 20, 1959, p. B-20, col.1. (Emphasis added.)

85 San Francisco Chromicle, June 21, 1959, p. 18, col. 5.

86105 Conc. REc. 7166 (daily ed. May 12, 1959). Enest A. Engelbert, of the University of California at Los Angeles, writes: "States operate under a handicap in the resources ficld because a general suspicion exists that the States are not strong enough to protect the public interest. Historically speaking, this is well-justified. . . Furthermore, interest groups dealing in natural resources appear to dominate state legislatures and administrative agencies in a number of states, particularly in the West.... [T]he Federal Government can counter-balance undesirable state and regional pressures with pohtical pressures from other regions and nationally." Bureat of Public Administration, University of Cat., Central Valley Project: Federat or State? 286-87 (May, 1955).

87 The fate of the water bond issue depended on many considerations besides the excess land law, important as this was. The San Francisco Chronicle, for exanple, which had been neither unfriendly to passage of the water bill by the legislature, nor friendly to an excess land provision, said editorially within a week: "Beyond dispute, the water bill as written and adopted under pressure leaves scores of the most pertinent questions unanswered. Unless they are answered to our satisfaction, this newspaper cannot conscientiously support this bond issue." San Francisco Chronicle, June 23, 1959, p. 34. The same editorial page carried excerpts from a talk by Samuel B. Morris, formerly general manager and chief engincer of the Los Angeles Depart- 
next step is a giant bond issue of $\$ 1,750,000,000$, or about twice the size of federal investment in Central Valley in the last twenty years. The bonds are general obligation, not revenue bonds. Sectional and other differences of interest and opinion remain. These are among the serious considerations that cast doubt upon the outcome of popular vote on the Governor's bond issue in 1960.

\section{III}

EXECUTIVE

[T] he present acreage limitation ... should be complied with, until the District has fully discharged its obligations to the Federal Government.Secretary of the Interior Fred A. Seaton, $1957^{88}$

My concern is with the use of an administrative order to overturn an act of Congress.... Neither the 81st nor the 82nd Congress accepted Congressman Werdel's twice-offered invitation to approve the interpretation that Secretary McKay advanced, and that you are offering to water users now. ... Within the past thirty days ... the Senate has struck down after four long days of searching debate an exemption from the excess land law on lands adjacent to Kings River.... You will realize my shock, therefore, Mr. Secretary, to learn from a news dispatch ... that your subordinates are again offering to honor the protested interpretation of law on Kings River that will turn the statutory limitation into a mockery.-Senator Paul Douglas, $1957,1959^{89}$

Secretary of the Interior Fred A. Seaton has authorized negotiation of repayment contracts on Kings River and Tulare Lake project ${ }^{89 a}$ that will not require large landholders to dispose of their excess holdings to obtain water as prescribed by the excess land law. ${ }^{30}$ The limitation will not apply when a district has "fully discharged its [financial] obligations to the Federal government," apparently whether payments are conipleted after the customary 40 years of interest-free installment payments or by a single lump sum prepayment..$^{11}$

${ }^{88}$ Letter from Secretary of the Interior Seaton to Philip A. Gordon, president, board of directors, Kings River Conservation District, July 12, 1957, copy on file in Bancroft Library, University of California, Berkeley. (Emphasis added.)

89 Letter from Senator Douglas to Secretary of the Interior Seaton, Dec. 16, 1957, reproduced in Hearings on S.1425, S.2541, and S. 3448 Before the Subcommittee on Irrigation and Reclanzation of the Senate Committee on Interior and Insular Affairs, 85th Cong., 2d Sess. 23 (1958) [hereinafter cited as 1958 Hearings on S.1425, S. 2541 \& S.3448]; Letter from Senator Douglas to Secretary of the Interior Seaton, June 9, 1959, copy on file in Bancoft Library, University of California, Berkeley.

89a This project was authorized by the Flood Control Act of 1944 , ch. $665, \S 10$, 58 Stat. $891,901$.

${ }^{90}$ Letter from Secretary Seaton to Philip A. Gordon, supra note 88.

01 Newspapers report contract negotiations in progress that offer Kings River districts the option of avoiding disposal of excess lands by prepayment, and an expectation among Sacramento regional officials of the Bureau of Reclamation that the contracts will be approved by the Secretary. See infra, text at note 169 . 
Douglas McKay, Secretary Seaton's immediate predecessor, tendered the same offer with but a single difference. Secretary McKay was ready to permit either individual excess landholders or entire districts, by making a lump sum prepayment, to avoid the necessity of disposing of their excess holdings. ${ }^{22}$ Secretary Seaton has made this option available only to districts. Both grounded their authorization on the argument that when financial obligations are met, the law does not require continued compliance with the 160-acre limitation.

In an exchange of correspondence with Senator Paul Douglas, ${ }^{03}$ Secretary Seaton set forth the grounds on which he relies in defending his authorization of such negotiations:
You will appreciate, I am sure, my reluctance to overturn by administrative order, an interpretation of 43 years' standing which could have been modi- fied legislatively by Congress on numerous occasions while considering bills or enacting laws pertaining to that subject. This does not infer that $I$ disagree with the basic interpretation that has been so long applied. But even if $I$ were in disagreement, I do not believe it would be proper for me to overturn at this late date a construction tacitly approved by Congress and thereby unsettle many property rights in the West. ${ }^{04}$

The arguments advanced may be conveniently summarized: (1) the interpretation of the law relied on is one of 43 years' standing; (2) the interpretation has "tacit" congressional support in the form of (a) approval of contracts containing the disputed provision, and (b) failure to act to change the law to counteract the administrative ruling; (3) property rights, built on the interpretation, would be unsettled by its abandonment. These argunents will be considered seriatim.

02 Letter from Secretary of the Interior McKay to C.J. Eaggerty, secretary-treasurer, California State Federation of Labor, March 2, 1954, copy on file in Bancroft Library, University of California, Berkeley.

${ }^{93}$ Letter from Senator Douglas to Secretary of the Interior Seaton, Dec. 16, 1957, reproduced in 1958 Hearings on S.1425, S.2541 \& S.3448, at 23. Senator Douglas placed the correspondence in the Record on April 30,1958; at that time he had received no reply to his last letter to the Secretary, written 16 months earlier, which the Secretary said he had referred to Department of the Interior Solicitor Elmer F. Bennett "for consideration and reply."

04 Letter from Secretary of the Interior Seaton to Senator Douglas, October 21, 1957, reproduced in $i d$. at 21 . This statement is in part a repetition of a thesis stated 3 years earlier by Secretary McKay, who said that "in view of the period of time that has elapsed since the ruling mentioned above and the actions that have been taken directly or indirectly in reliance upon it, it is iny view that the Department is constrained to follow the precedents already set, unless they should clearly be demonstrated to be wrong or unless the law is changed." Letter from Secretary of the Interior McKay to George Sehlmeyer, master, California State Grange, March 2, 1954, reproduced in U.S. Dep'T of THE INTERTor, EXCEss LaND Provistons of tIEE Federat Rectamation Laws and the Payment of Chafges, pt. 1, app. 61:2 (May, 1956) [hereinafter cited as Excess LaNd Provisrons]. (Enphasis added.) No evidence can be found that the opinion has ever come before the courts. Secretary Seaton was willing (at least for the sake of argument) to go one step beyond Secretary McKay by vaaiving the condition, "unless . . clearly . . . demonstrated to be wrong." 
(1) The Secretary's first argument is that the interpretation of the law on which his action rests is one of " 43 years' standing." The reference date is unconvincing. The first departmental expression of opinion on the subject is found in an administrative hearing held in 1913. It was there stated that the completion of payment had no effect on the applicability of the excess land limitation, and that "the language on this point is susceptible of but one construction...." In In 1914, an opinion of Reclamation Service Counsel, Will R. King ${ }^{96}$ - the basis of Secretary Seaton's argument-was submitted, but it lay dormant for many years without action in reliance on it. In 1947, thirty-three years after the opinion was written and only 12 years before the time at which Secretary Seaton is speaking, the Commissioner of the Bureau of Reclamation, Michael W. Straus, was uncertain as to the proper interpretation of the law; he was unwilling to rely on the 1914 King Opinion without further legal advice.97 The Commissioner has since placed the beginning of concern over the question in 1947, with the most intense activity being delayed until the end of 1951 and the beginning of $1952 .{ }^{98}$

At least through 1952, Straus' original doubts as to the reliability of the interpretation were widely shared by California interests. Congressman Thomas H. Werdel introduced bills in $1950^{99}$ and in $1951^{100}$ to assure that in relation to Kings River the completion of payments would remove the limitation of the excess land law. Neither bill passed.

The failure of these bills in Congress did not deter either Secretary McKay or Secretary Seaton from authorizing negotiation on the basis that completion of payment would remove the excess land limitation. They had some further legal support, however. A 1947 memorandum of Interior Department Associate Solicitor Felix Cohen-given in reply to Commis-

85 Keebaugh \& Cook, 42 L. Dec. 543, 545 (1913). (Emphasis added.) For a review of early opinions, see also U.S. BUREAU of REcLAMAation, DEP'T of THE INTERTOR, IAANDOWNERSHTP Survex on Federat Rectamation Projects 32-42 (1946).

${ }^{96}$ Edwin E. Kaine, 43 L. Dec. 339 (1914). This has been accepted subsequently as the only authoritative expression on the matter. The earlier ruling has been ignored, and it is as if King's opinion had been substituted for it. It was King's opinion which formed the only basis for the Cohen Memorandum. See infra, text at note 102.

97 See infra, note 102.

98 "Reclamation has now been engaged in seeking resolution of this matter for six years and most intensively for 13 months without success." Letter from Commissioner of the Bureau of Reclamation Michael W. Straus to Secretary of the Interior McKay, Feb. 4, 1953, reproduced in Excess Land Provisions, op. cit. supra note 94, pt. 1, app. 56:1. (Emphasis added.)

90 H.R. 7915, 81st Cong., 2d Sess. (1950). See infra, note 100.

100 H.R. 413, 82d Cong., 1st Sess. (1951). These were identical bills, introduced March 29, 1950, and January 3, 1951, respectively. Proposed to make mandatory acceptance of lump sum payment and "in consideration of" this payment specified that the water users of Kings River would receive right to the "perpetual use for irrigation purposes, in such manner as such water users deem desirable, of the entire flow (including flood waters) of the Kings River, subject only to" United States flood control regulation of Pine Flat Dam. 
sioner Straus' inquiry ${ }^{101}$ _relied on the King Opinion of 1914 without examination or question. ${ }^{102}$ In addition, Secretary Seaton had received from Solicitor Elmer F. Bennett the advice that "further review" of the interpretation of the law embodied in the King-Cohen Opinion was not "warranted at this time." 103

Nevertheless, Secretary McKay remained sufficiently unsure of the legality of the interpretation to leave office in the Spring of 1956 without signing the Kings River contract which his subordinates had negotiated on terms he had previously authorized. ${ }^{104}$ On July 12, 1957, Secretary Seaton refused to sign the contracts which Secretary McKay had left unsigned. He noted that "a very large part, approximately one-fourth" of the lands on the Kings River project, is in excess holdings. ${ }^{105}$ The contract

101 See supra, text at note 97.

102 Felix S. Cohen, Associate Solicitor, U.S. Dep't of the Interior, Memorandum M-35004 to Commissioner, Bureau of Reclamation, Oct. 22, 1947, reproduced in Excess LAND Provisrons, op. cit. supra note 94 , pt.1, app. 27 . The memorandum was given in reply to Commissioner Straus's question: "Does the payment in full of construction charges against 'excess lands' free such lands of the acreage limitations of the reclamation laws . . . ?" The answer given was in the affirmative. Associate Solicitor Colsen relied on King's 1914 Opinion without examination or question. In turn, the Cohen Opinion has been relied on since 1947. Hereinafter, the interpretation of the reclamation law embodied in these opinions will be referred to as the "King-Cohen Opinion."

It should be noted that the phrasing of the Commissioner's question is inharmonious with the language of a later decision of the Supreme Court of the United States. He speaks of freeing lands;" the Supreme Court said that the reclamation law was "designed to benefit people, not land." Ivanhoe Irr. Dist. v. McCracken, 357 U.S. 275, 297 (1958).

103 Memorandum accompanying Letter from Secretary of the Interior Seaton to Senator Douglas, Oct. 21, 1957, reproduced in 1958 Hearings on S.1425, S.2541 \& S.3448, at 21. The King-Cohen Opinion rests on grounds the author has analyzed in detail, concluding that "it is difficult to find reasonable ground either in the law or it; legislative history to explain why administrators have accepted ... [it], apparently without question." Taylor, Excess Land Law: Execution of a Public Policy, 64 YaLE L.J. 477, 501 (1955). This analysis need not be repeated here. However, it may be noted that data discovered in subsequent research strengthen an answer previously given. King had supported his interpretation by analogy to what he alleged to be fact, viz., that Congress never had placed a hmit in prior land laws on "the amount of land which a man may own after having complied in full with the provisions of the law in order to acquire the title. . . " Edwin E. Kaine, 43 L. Dec. 339, 340 (1914). (Emphasis added.) King overlooked at least four contrary examples: one from the homestead laws of 1889, 25 Stat. 854,43 U.S.C. $\$ 214$ (1952); another in reclamation laws barely 3 years prior to his giving the opinion, 36 Stat. 925 (1911), 43 U.S.C. $\$ 524$ (1952); the third, a 5000-acre himitation on corporate landownership in territories, the Act of May 3, 1887, ch. 340, \& 3, 24 Stat. 476; and the fourth, a 500-acre hmitation on corporate landownership in Puerto Rico, 31 Stat. 715 (1900), 48 U.S.C. \& 752 (1952).

104 The Flood Control Act of 1944, 58 Stat. 901, 33 U.S.C. $\$ \$ 701 f, j$ notes (1952) had authorized lump sum payment on Kings River without specifying any consequences as to policy.

105 Letter from Secretary of the Interior Seaton to Philip A. Gordon, president, board of directors, Kings River Conservation District, July 12, 1957, copy on file in Bancroft Library, University of California, Berkeley. It should be remembered that on this point there is little difference between Secretaries Seaton and McKay. 
in question "extended to each water user, would reduce the statutory limitations to a mere shadow. This would make the test, not one of public policy, but solely one of the financial capability of each landowner to purchase immunity from the statutory restrictions." 100 This record suggests that the administrative interpretation of the law is neither certain nor of "long standing." At least, Secretary Seaton's predecessors have not indicated by their behavior that it was-not even Secretary McKay.

(2) The second ground on which Secretary Seaton relies is that Congress has given "tacit" approval to the interpretation embodied in the KingColren Opinion. Beginning in 1949, apparently, clauses have been written into some repayment contracts providing that, on completion of the payments, the excess lands provisions becoine inoperative. The precise number of contracts actually drawn up in this fashion is not available, but Commissioner Straus has stated that the clause was to be found in "dozens of repayment contracts."107 On the other hand, an official listing shows that, in the 4-year period between 1949 and 1952, only eleven such contracts were submitted to Congress and approved by it. ${ }^{108}$ After the cliange in the national administration at the beginning of 1953, thirteen more were given approval in less than $2 \pi / 2$ years..$^{100}$

The nature of the congressional approval of these contracts suggests that little, if any, consideration was given to the clause in question, because -if for no other reason-the occasion for the submission of these contracts to Congress was not the inclusion of provisions embodying the disputed interpretation. ${ }^{110}$ Secretary Seaton, in elaborating his argument, states that congressional approval has been given "tacitly," because if Congress had objected to the administrative interpretation of the law, it could lave modified it "on numerous occasions while considering bills or enacting laws pertaining to that subject."111 Senator Douglas, in reply, remarked that the memorandum accompanying the Secretary's letter cited "no instances

108 Ibid.

107 Commissioner of the Bureau of Reclamation Michael W. Straus, Memorandum for the Record, Feb. 6, 1953, reproduced in Excess LAND Provistons, op. cit. supra note 94, pt. 1, app. 54:1. Significantly, Commissioner Straus also spoke of these contracts as "recently approved." Letter from Commissioner Straus to Secretary of the Interior McKay, Feb. 4, 1953, reproduced in Excess Land Provisrons, op. cit. supra note 94, pt. 1, app. 56.

108 Id., pt. 1, at 49-54.

100 Ibid.

110 "These contracts have been executed during the period from 1949 to 1955 and as such, of course, are representative of contracts under a relatively small portion of the total of reclamation projects. Part of these contracts were submitted to and approved by the Congress pursuant to Section 7 of the Reclamation Project Act of 1939. Their authorization in this manner was occasioned by the inclusion of substantive provisions unrelated to the express recognition which they contain concerning the payment of charges and the application of the excess land limitations." Id. at 49-50. (Emphasis added.)

111 See supra, text at note 94. 
of Congress' express knowledge, discussion or recognition of the King interpretation. To construe a failure to act as a tacit approval under these circumstances is surely more of an exercise in mind reading-the subconscious mind, I mean-than in logical argument." 112 It may be added that the Secretary, for all his zeal in finding evidence of tacit congressional approval, appears to have overlooked the rather convincing evidence of congressional disapproval to be found in the repeated rejection of bills explicitly embodying the interpretation. ${ }^{113}$

(3) The final phase of Secretary Seaton's argument is that Western property rights built upon the administrative interpretation of the law would be unsettled if it were now abandoned. It would be more accurate to speak of unsettling the hopes and expectations of property owners holding, or hoping to hold, excess land. ${ }^{114}$ The interpretation of the laws on which these hopes are based was not acted on until it found a place in contracts drawn up 47 years after the original passage of the reclamation law. ${ }^{116}$ Rumors of its application on Kings River brought sharp protest. ${ }^{116}$ Under criticism, Secretaries Chapman and McKay refrained from actually applying the interpretation to the conspicuous excess land holdings of the Kings River project. ${ }^{117}$ It is unlikely that either would have failed to protect property rights by standing firm on the King-Cohen interpretation had they believed there were any legally recognizable property rights to protect. Instead, Secretary Seaton refused in 1957 to sign the Kings River project contract, negotiated under Secretary McKay, witl the contested interpreta-

112 Letter from Senator Douglas to Secretary of the Interior Seaton, Dec. 16, 1957, reproduced in 1958 Hearings on S.1425, S.2541 \& S.3448, op. cit. sicpra note 89, at 23. See also id. at 23-24, where Senator Douglas says: "I would prefer, as I think you would, to be able to rely on administrative responsibility for a continuous check of the correctness of its own interpretations of statute, rather than require a continuous and meticulous congressional investigation of the administration of law that Mr. Bennett's argument seems to invite if not necessitate."

113 See supra, text at notes 99, 100.

114 Non-enforcement of the excess land laws is familiar and confers benefits on those for whom the law did not intend them, but these benefits are not property rights. The limitation on corporation landownership in Puerto Rico went unenforced for close to four decades, but no recognizable rights were acquired thereby. People v. Hermanos, Inc., 309 U.S. 543 (1940). A spokesman for Tulare Lake Basin Water Storage District has recognized "lax" and "cntircly missing" enforcement among possible "solutions" at hearings in which his preferred solution was to remove the law by congressional action. "[It] . . . would not be a safe solution herc. Landowners could not rely on continued future non-enforcement." Testimony of S. T. Harding, Hearings on S. Res. 295 Before the Subcommittee on Irrigation and Reclamation of the Senate Committee on Interior and Insular Affairs, 78th Cong., 2d Sess. 363 (1944).

11532 Stat. 390 (1902), 43 U.S.C. \& 372 (1952), re-enacted, 44 Stat. 649 (1926), as amended, 43 U.S.C. § 423 (e) (1952). See supra, note 107.

${ }^{116}$ See statement of M. C. Hermann, quartermaster-adjutant, Department of California, Veterans of Foreign Wars, read into the Record by Congressman John F. Shelley, 97 Cono. Rec. 6351-52 (1951). See also Excess Land Provisions, op. cit. supra note 94, pt. 1, app. $29: 32-: 53,: 63,: 100$.

117 See supra, text at note 104. 
tion because it offered exemption from the law to individual excess landowners. He was apparently undisturbed at that time by any thought that he might be unsettling property rights established under these contracts.

An inquiry into the various pressures exerted on the relevant officials is more revealing than further examination of the legal arguments advanced. The source of the pressure is excess landowning interests seeking to escape from the legal limitation on their share of benefits from federal reclamation projects. Pressures are exerted, not only by direct resistance to signing contracts, but also in various other ways. The Bureau of Reclamation has suffered severely in some instances, notably on Kings and Kern Rivers, by losing to Army engineers congressional authorization to construct these projects. ${ }^{117 a}$ The influence of excess landholders seeking to avoid disposal of excess holdings was decisive against the Bureau in both instances. In the heat of the conflict over enforcement of the excess land law in Central Valley in 1948, a Senator persuaded Congress to deprive Commissioner Straus and Sacramento Regional Director for the Bureau of Reclamation, Richard Boke, of their salaries for 5 months by attaching a rider to an appropriation bill excluding them from the payroll and leaving them uncertain whether they would ever be returned to it. ${ }^{118}$

The following is an example of how the influence exerted by these interests have shaped the course of repayment contract negotiations relating to Kings River project in the past 7 years. On January 18, 1952, Commissioner Straus wrote:

No ... agreement has been reached, and it is the hope of the water users to get this conservation water for free without any repayment and outside of all the reclamation law, including the 160-acre clause .... The Kings River group is negotiating with the philosophy that, if, in truth, they are ever required to make any payment or recognize any part of the Reclamation law, they would go the "Iump sum settlement" route, and thereby divest themselves of the acreage restriction obligation. This has troubled the Bureau of Reclamation which is under numerous mandates to negotiate to a successful conclusion with the Kings River group. The particular relationship to the acreage restriction clause has so troubled Regional Director Boke that he has written the attached memorandum of policy inquiry .... In the absence of any recognition of any kind of Reclamation law or any agreement as to any repayment by water users for Pine Flat water, $\mathrm{I}$ am of the tactical opinion that we should effect and conclude a "lump-sum repayment" contract under the philosophy of the Associate Solicitor's Opinion M-35004. By that procedure, I believe we would come nearer serving public interest than we would if, on imminent completion of the Kings 
River Dam, the water users enjoyed the benefit of that conservation water with no repayment and no recognition of any Reclamation law. ${ }^{110}$

In other words, the decision on the part of the Commissioner to act in accord with the disputed interpretation allowing relief from the operation of the 160-acre limitation was not founded on a belief that the law required him to do so, or even that the action was good policy, ${ }^{120}$ but that it was a proper tactic necessary in response to the determination of the landowners to "escape certain of the harshest applications of the 160-acre rule," i.e., the necessity of disposing with all excess holdings in order to obtain water. Pressure was having its effect, particularly on the Bureau. ${ }^{121}$

Secretary Chapman had found it "gratifying" in relation to earlier negotiations, ${ }^{122}$ based on the escape-hatch interpretation of the reclamation law, to report that this had nade it possible for landowners to bring "themselves into coinpliance with the acreage limitation provisions." ${ }^{123}$ On the other hand, apparently sensitive to local political concern spotlighted by protests by eiglit California Congressinen, lie reassured them that "in the entire State of California no situation exists on a Federal Reclamation project where Administrative Letter 303 has been applied or is being considered." 124 On October 21, 1952, the Bureau of Reclamation never-

119 Letter from Commissioner Straus to Secretary Chapman, Jan. 18, 1952, reproduced in Excess Land Provisions, op. cit. supra note 94, pt. 2, exhibit $20: 2,: 3$. Three years earher a Hoover Commission task force report had pointed to difficulties arising from the attitude of excess landholders on Kings River: "It may well be that the Federal Governunent will never turn a thin dime for a large part of the irrigation benefits provided by this project, and the benefits will accrue to the present owners of land rather than to the small independent farmer around whom the whole philosophy of Federal reclamation has been built." Maass, Kings River Project in the Basin of the Great Central Valley-a Case Study, [Hoover] U.S. Comon's on Organization of the Executive Branch of the Governament, Concluding Report, App. L, TASK Force Report on Naturad Resources, January 1949, app. 7, at 178 (May, 1957).

120 "I do not know whether this theory [lump sum payment] settles the water users' obligations ... which also embrace compliance with the 160-acre law." Letter from Commissioner of the Bureau of Reclamation Straus to Secretary of the Interior Chapman, Jan. 18, 1952, reproduced in Excess LaND Provisions, op. cit. supra note 94, pt. 2, exhibit 20:1, :2.

121 "Although it is true that Mike [Commisissioner Straus] las been crucified on this cross before, I fear I detect a weakening in the Bureau's position, possibly because it is feared that continuing to stand pat on this and other matters may jeopardize a large future construction program." Letter froin Arthur A. Maass, assistant professor of government, Harvard University, to Joel Wolfsohn, assistant to the Secretary of the Interior, Oct. 28, 1951, reproduced in Excess Land Provisions, op. cit. supra note 94, pt. 1, app. $32: 3$.

122 Commissioner of the Bureau of Reclamation Straus, Administrative Letter No. 303, Dec. 16, 1947, reproduced in Excess Laxd Provisions, of it. cit. supra note 94, pt. 1, app. 26. See also id., pt. 1, apps. 27, 28; Letter from Richard L. Boke, Regional Director, Bureau of Reclamation, to Commissioner of the Bureau of Reclamation Straus, Oct. 31, 1951, id., pt. 1 , app. 31 .

${ }^{123}$ Letter from Secretary of the Interior Chapman to Congressman Joln F. Shelley, March 29, 1951, reproduced in $i d$, pt. 1, app. 29:2.

124 Ibid. On November 21, 1951, he advised James G. Patton, president of the National Farmers Union, that the Department, the Bureau, and le, personally, were strongly committed to the family-size farm principle, and that he was "confident that no responsible official of the 
theless communicated to the Kings River Conservation District its willingness to accept lunip sum payment with the understanding that such payment "would remove the excess land restriction of Reclamation Law."125 In correspondence with Secretary Chapman at about the same time, Commissioner Straus argued that the "mitigation," allowed under the KingCohen Opinion, would represent compliance with the reclamation law. He said that this ruling was "the vehicle of the Department in enunciating its policy," and that the King-Cohen Opinion has been "approved by the Secretary of the Interior, and that thereby it was entrenched as policy until modified." 128 In a later letter, he taxed the Secretary with having "consistently withheld commitment" on the Kings River negotiations and, represented that the basis of these negotiations was "established Department policy and practice consistent with" the King-Cohen Opinion "construing the Federal statutes. ..." 127

A personal protest to President Truman by President James G. Patton of the National Farmers Union brought the cleavage between the Bureau and the Department into focus. ${ }^{128}$ Secretary Chapman soon made it clear that a sharp division on the policy of accepting prepayment as a means of avoiding the excess land law existed between Department and Bureau. ${ }^{129}$ He denied that the Department liad "fornalized is policy" in this respect.

Bureau of Reclamation has proposed that the provisions of Reclamation law be subverted or evaded." Letter from Secretary of the Interior Chapman to James G. Patton, Nov. 21, 1951, reproduced in $i d$. . pt. 1, app. 38. At the same time, he advised the Bureau of Reclamation that he was "not in favor of discarding the 160-acre limitation" and assumed that "no commitments are being made on behalf of the Bureau or the Department which will in any way deviate from the provisions of the law and the policy which we have supported here consistently." Letter from Secretary of the Interior Chapman to Commissioner Straus, Nov. 21, 1951, reproduced in $i d .$, pt. 1, app. 35.

125 Letter from Jack W. Rodner, District Manager, Bureau of Reclamation, to Kings River Conservation District, Oct. 21, 1952, reproduced in id., pt. 2, exhibit 27:2.

${ }^{128}$ Letter from Commissioner Straus to Secretary of the Interior Chapman, Jan. 18, 1952, reproduced in $i d$. , pt. 1, app. 36:1, :2. See also id., app. 40.

"I cannot see the Department sanctioning a ruse (lump sum payment) to get around the law. . . Like Ickes, Secretary Chapman has always taken a good stand on these matters. ... I do not think the Secretary should allow the Bureau to weaken. I hope you can lielp shore them up." Letter from Arthur A. Maass to Joel Wolfsohn, Oct. 28, 1951, reproduced in id., pt. 1, app. $32: 2,: 3$. See also $i d$., apps. $33,34$.

${ }_{127}$ Letter from Commissioner Straus to Secretary of the Interior Chapman, Dec. 4, 1952, reproduced in id., pt. 1, app. 46.

${ }^{128}$ At that time, Patton presented a letter of protest to President Truman rclating to Kings River contract negotiations. It stated that "unless you act fast and decisively, your Administration is about to go down in history, ironically, as the one that pulled the plug on American family farm policy and sent it down the drain, instead of the one that defended it heroically to the last against all attacks." Letter from James G. Patton, to Harry S. Truman, Nov. 24, 1952, reproduced in id., pt. 1, app. 46:4.

120 Commissioner Straus claimed later that Secretary Chapman told him orally on January 6, 1953, to "disregard the order" of December 23, 1952 that acceptance of prepayment anywhere, including Kings River specifically, was contrary to Department policy. Commis- 
For the purpose of correcting the record, I wish to point out that the [King-Cohen] opinion does not in itself set forth any policy, and since it does not contain any pohicy pronouncement, there was no occasion for the submission of the opinion to the Secretary of the Interior for approval, and it was not so submitted. ${ }^{130}$

\section{The sharpness of this division may be pointed up by a comparison of the following:}

(1) Commissioner Straus:

[T] he Commissioner reviewed some of the highlights of past battles over acreage limitation; said he viewed the "Iump-sum payment clause" in reclamation contracts as a politically necessary escape hatch, but nevertheless a "phony" because it would almost never be used; said that without such "safety valves" as this, the acreage limitation principle would be wiped completely off the books by Congress .....131

(2) Secretary Chapman:

The present policy of the Department of the Interior ... should now be entirely clear. Except in those situations noted in the preceding paragraph, ${ }^{132}$ lump-sum or accelerated payment of construction charges is not to be used as a means of avoiding the acreage limitation provisions of reclamation law. ${ }^{133}$

Secretary McKay, however, chose to erect Secretary Chapman's "exceptions" into the general policy of the Department. In doing so, he said

sioner Straus, Memorandum for the Record, February 6, 1953, reproduced in id., pt. 1, app. 54:2. See also id., app. 55. A member of the Program Staff doubted that Secretary Chapman had withdrawn the order on policy, noting that the original remained in the Secretary's files and had been referred to "affirmatively and with emphasis" as stating "clear Department policy," in a letter to Senator Douglas, dated January 19, 1953. Letter from Fred A. Clarenbach, Program Staff of the Department of the Interior, to the files, Feb. 3, 1953, reproduced in $i d$., pt. 1, app. 55:1,:2.

130 Letter from Secretary of tbe Interior Chapman to Commissioner Straus, Dec. 23, 1952, reproduced in id., pt. 1, app. 47. In Patton's opinion, Secretary Chapman's statement was insufficient because, while affirming satisfactory policy on Kings River, effective during the reing days of the outgoing administration, it left the King-Cohen Opinion (note 102 stupra) and Administrative Letter No. 303 (note 122 sitpra) undisturbed. See Letter from James G. Patton to Secretary of the Interior Chapman, Jan. 12, 1953, reproduced in id., pt. 1, app. 52. See also id., pt. 1, apps. 49-53.

131 Letter from Fred A. Clarenbach, Program Staff of the Department of Interior, to the files, Feb. 3, 1953, reproduced in $i d$. pt. 1, app. 55:1.

132 See Letter from Secretary Chapman to Harry S. 'Truman, Dec. 24, 1952, reproduced in $i d$., pt. 1, app. 48, where the situations are discussed. Secretary Chapman mentioned the conclusion of the Colien Opinion as to the law, and acknowledged that the Department, under Administrative Letter No. 303, had accepted "an accelerated payout from some excess landowners in ... some of the older projects." Pressures upon hin from persons and organizations supporting the principle of the law evidently were too bittle and too late to be wholly efiective. Ibid.

133 The Secretary acknowledged acceptance of accelerated payment "in certain situations," and described them as "exceptions" to policy. Letter from Secretary Chapman to Senator Douglas, Jan. 17, 1953, reproduced in id., pt. 1, app. 50. 
that he was "constrained to follow the precedents already set." 134 The use of the lump sum payment device to avoid the excess land limitation was felt to be "not novel, nor did it originate . . . 'with the present administration of the Department." "134a Although, as noted above, ${ }^{135}$ Secretary Seaton repudiated a Kings River contract negotiated under this philosophy, that offered individual landowners exemption from the law, he simultaneously proposed the terms for new negotiations. The difference between the basis of the old negotiations, and that of the new, was slight. Where Secretary McKay had authorized exemption from the limitation to both individuals and districts, the new offer was extended to districts only. ${ }^{136}$

Despite Secretary Seaton's ringing words in refusing to sign the already negotiated contract, ${ }^{137}$ he did not point out that two-thirds of all excess lands on the Kings River project are concentrated in a single district; that of all lands of that district they constitute about 90 percent; and that they represent about 90 percent of the voting power, which is based on assessed valuation. He did not explain how the evident prospect that this entire district-Tulare Lake Basin Water Storage District-would choose pre-

134 Letter from Secretary of the Interior McKay to George Sehlmeyer, master, California State Grange, March 2, 1954, reproduced in id., pt. 1, app. 61:2.

134a Letter from Assistant Secretary of Interior Aandahl to C. J. Haggerty, secretarytreasurer, California State Federation of Labor, Aug. 6, 1954, reproduced in id., pt. 1, app. 64:2. "We assure you that the present administration of the Department has no intention, by this decision or any other, ' . . to break the back of family farming in California and the west.' "' Ibid. In 1957, there were 266,302 acres in excess holdings on the Kings River project, These could provide 160 -acre farms for 1,664 families or for 3,328 farms of 80 acres each, which approximates closely the average size of irrigated farms in Cahfornia. Letter from Secretary of the Interior Seaton to Philip A. Gordon, July 12, 1957, copy on file in Bancroft Library, University of California, Berkeley.

135 See supra, text at note 104 .

${ }^{138}$ See supra, text at note 91 . Secretary Seaton has employed the same tactic twice at critical points, viz., played down or ignored the more important question and played up the less important one: (1) Rejecting the McKay contract in 1957, he passed over the central question whether excess landowners could avoid disposing of excess lands by payment; instead, he called "the overriding issue" whether they could do this as individuals or only through district action. (2) Seeking legal advice from the Attorney General of the United States in 1958, he ignored the central question again; instead, he asked whether reclamation law applied to Kings River, the answer to which no Secretary of the Interior before him lras doubted-not even Secretary McKay.

${ }^{187}$ See supra, text at note 106. Secretary Seaton had also said that "I am fully aware that over the years there have been legal opinions presented and approved which have permitted individual landowners to avoid the excess land limitations of the law by a prepayment of their administratively allocated slare of construction costs. However, I cannot justify an aggravation of a prior practice in an effort to remedy an absence of lawful authority .... I conceive it to be ... my duty as Secretary, to exert every effort to see that applicable laws are complied with. Where discretion unay be vested in the Department or the Secretary, that discretion slould be exercised to obtain compliance with the principles on whicl the legislation is enacted. What I am concerned about is a process by which inferences are based on inferences and there is a whittling away at a principle until all that is left is a pile of slravings." Letter from Secretary of the Interior Seaton to Philip A. Gordon, supra, note 134a. 
payment to avoid disposing of excess lands could be reconciled with the principles he recited as reasons for rejecting the contracts offering exemptions to individuals.

The small margin of difference between the authorization for negotiations from the two Secretaries is reflected in the similarity of their arguments in justification of their actions. Commissioner Straus had argued that allowing the law to be avoided was an "escape hatch" advisable in face of determined resistance from excess landholders. Secretary McKay, by contrast, said that he was, in this matter, "constrained to follow . . . precedents;" Secretary Seaton said that it would not be "proper" for him to "overturn at this late date" the administrative interpretation of the law. This "long-standing interpretation," however, had been rejected by Secretary Chapman only a few years before and in the face of pressure sufficient to nuake the Bureau of Reclamation turn to it as a necessary tactic.

It is clear that Secretary Seaton's defense of his actions cannot be justified on the terms he has chosen for that purpose. Law and precedent fail to provide a solid foundation for claims that officials are constrained to allow the avoidance of the excess land limitation of the law by the device of lump sum payment of the costs of construction or by completing those payments over a 40-year period.

\section{IV}

\section{WATER DISTRICT}

The property owerners in the Tulare Lake Basin Water Storage District... see no way to clearly meet the financial requirements of any contract with the Bureau, in order to avoid the application of the 160-acre limitation rule. Many of the property owners in other irrigation districts near Fresno... do not ozen in excess of 160 acres, and apparently they have the majority of representation on the Kings River Water Association, and may have been giving ... the impression that there is no objection to negotiating a permanent contract with the Bureau. However, the larger landowners, and especially those in the Tulare Lake Basin Water Storage District, are strenuously opposed to this procedure.-Eugene E. Marsh, 1955188

We doubt if we will ever get all the ins and outs of this water and irrigation business through our heads ... after the question and discussion period which followed the talks it seemed we knew even less.-Cutler-Orosi Courier, $1951^{139}$

The federal government completed construction of Pine Flat Dam in

138 Letter from Eugene E. Marsh, attorney at law, McMinnville, Oregon, to Secretary of the Interior McKay, July 28, 1955, reproduced in U.S. DEP'T OF THE INTERToR, ExCESS Land Provistons of the Federat Reclanation Laws and the Paysoent of Charges, pt. 2, exhibit 40:3 [hereinafter cited as ExCEss LAND PROvistons].

139 (Orosi, Cal.), Aug. 23, 1951, p. 1, cols. 1, 5, under the lead, "Kings River Water Users Hear New Organization Explained at Reedley Meeting." The "new organization" was the Kings River Conservation District. 
1954 for the benefit of water users on Kings River and Tulare Lake project at a cost of around $\$ 40$ million. More than a score of districts or agencies distribute water to the lands of the project. They receive water under annual interim contracts, arranged through an overall district created in 1951, known as the Kings River Conservation District (KRCD). Neither the KRCD nor the individual districts have made arrangements for repayment of construction charges and permanent water supplies, although correspondence on the subject dates from as early as $1946 .^{140}$ The reason for this extraordinary delay is the determined and persistent opposition of excess landowners to inclusion of the standard excess land provisions in the contracts, as required by reclamation law.

The concentration of this economic interest is impressive. Approximately two-thirds of the 266,302 excess acres on the project are located in Tulare Lake Basm. Fifty-two owners hold 196,466 excess acres, or almost three-quarters of the excess lands on the project. This concentration creates a strong economic interest in defeat of the excess land law on Kings River. About one-fourth of all the milion acres on the Kings River and Tulare Lake project are in excess holdings. ${ }^{141}$

Most of the lands of the Kings River project area, however, are in parcels of less than 160 acres. Their owners constitute almost 92 percent of all landholders and are unaffected by the federal requirement of an agreement to dispose of excess lands as a condition of obtaining water. Their desires and interests might easily have led them, uninfluenced by others, to execute permanent contracts, as districts along the Friant-Kern Canal did close to a decade ago to secure permanent water rights from the Central Valley project. Some smaller landowners on Kings River have worked actively to obtain compliance with reclamation law, but in general their leadership has been fitful and unskillful.

Until 1951 the Kings River Water Association (KRWA) was the only organization coextensive with the project area and therefore the only one with even an appearance of speaking for all interests on the river. KRWA administered the distribution schedules of unstored water, without limitation of water deliveries based upon size of ownership. Although the purpose of the project was to improve water rights by a more efficient use of the river, the law requires equitable redistribution as a condition of their improvement. The spokesmen of KRWA opposed redistribution as an interference with established water rights, ${ }^{142}$ thereby ignoring the increment attributable to the project.

140 Excess LAND Provisrons, op. cit. suppra note 138, pt. 2 , at 5.

111 Letter from Secretary of the Interior Seaton to Philip A. Gordon, president, board of directors, Kings River Conservation District, July 12, 1957.

142 KIngs RIver Water Ass'n, KINGs RIVER-Facts ANd FaIsemoods 6-9 (1950); testimony of Charles L. Kaupke, engineer and watermaster, KRWA, Hearings on $H . R$. 4485 Before a Subcommittee of the Senate Committee on Commerce 78th Cong 2d Sess 305 (1944): 
The original tactic of KRWA resistance was to persuade Congress to authorize the Army Engineers rather than the Bureau of Reclamation to construct the Pine Flat project. ${ }^{143}$ The attempt to disassociate the law governing Pine Flat from the law governing Central Valley project required physical separation of the projects, as well as use of separate construction agencies. Physical separation was not achieved easily. Pine Flat was included in the plans of both State ${ }^{144}$ and federal ${ }^{145}$ governments for unified water development of Central Valley. The Friant-Kern Canal of the Central Valley project intersects the Kings River and could easily bring water to lands on Kings River and Tulare Lake that need it urgently. ${ }^{140}$ Nevertheless, because of resistance to reclamation law, the intersecting streams have been held separate artificially by siphoning Friant-Kern waters underneath the waters of the Kings River. However, these two devices-separate construction agencies and physical separation of projects - did not prevent Congress from applying the excess land law to Kings River, ${ }^{147}$ although they contributed to extraordinary postponement of its execution.

Since these tactics were undependable as means of avoiding the excess land law, large landholding interests found it desirable to keep negotiations with the Government in local hands that could be relied upon to resist completion of contracts accepting the excess land law. This required preventing individual districts from making contracts with the United States that they had power and genuine interest to conclude. Districts with the least excess lands, having least interest in resistance, would probably sign first. Few districts would be willing indefinitely to risk their own

143 On April 24, 1941, after the Bureau of Reclamation held a legal authorization to construct Pine Flat Dam, Charles L. Kaupke, then secretary and engineer, Kings River Pine Flat Association, told Congress that "rather than accept the provisions of the Bureau project, we would forego a project on Kings River." Hearings on H.R. 4911 Before the House Commillee on Flood Control, 77th Cong., 1st Sess. 181 (1941). A telegram from Tulare Lake Basin Water District, dated May 7, 1945, said: "Over the several past years we have been required to incur much expense in order to assist in preventing this project from being undertaken by the Bureau of Reclamation." Hearings on H.R. 3024 Before a Subcommittee of the Senate Committee on Appropriations, 79th Cong., 1st Sess. 991 (1946).

144 Cal. Div. of Water Resources, Reports on Stati: Water Plan, Buld. No. 29, San JOAQUIN RIVER BASIN 261-65 (1931) (prepared pursuant to Cal. Stat. 1929, c. 832, § 1).

145 S. Doc. No. 113, 81st Cong., 1st Sess. 216 (1949).

${ }^{146}$ Testimony of Louis T. Robinson (Kings County farmer), Hearings on S.178 Before the Subcommittee on Irrigation and Reclamation of the Senate Committee on Interior and Irtular Affairs, 84th Cong., 2d Sess. 140-41 (1956).

14758 Stat. 891 (1944), 43 U.S.C. $\$ 418$ (1952). See 41 OPs. ATr'y Gen. 56 (1958); Maass, Kings River Project in the Basin of the Great Central Valley-a Case Study, [Hoover] U.S. Commin on Organzzation of the Executive Brance of the Government, Concludino Report, App. I, TASK Force Report on NATURAL Resources, January 1949, app. 7, at 149-82 (May, 1957). See also Taylor, Excess Land Law: Execution of a Public Policy, 64 Yare L.J. 477 (1955); Taylor, Excess Land Law on the Kern?, 46 CALIF. L. Rev. 153 (1958). 
future water supplies while adjacent districts were signing contracts to make theirs secure. Each contract signed by an individual district on Kings River for a perinanent water supply would weaken the power of the remaining districts to hold out. Districts resisting longest would progressively lose support for their resistance, and risk losing their own future water supplies to districts signing earlier, which by compliance with the law would be entitled to priority $\mathrm{m}$ permanent distribution of water. ${ }^{148}$

Along the Friant-Kern Canal, where the situation was comparable, resistance to the acceptance of permanent contracts containing the excess land law was beginning to crumble at the first determined efforts of the Bureau of Reclamation to conclude them. In 1948 two districts along the Friant-Kern Canal signed four contracts containing the excess land provision and ratified by popular vote of 188 to 1 the only one requiring ratification. ${ }^{149}$ Three districts approved contracts in 1949 by a combined vote of 1,072 to $183 .{ }^{150}$ Five districts signed contracts in 1950, with a total popular vote for approval of 1575 to $121 .^{151}$ Similar action by at least some of the neighboring Kings River districts could reasonably have been anticipated in the absence of measures to delay or prevent it.

The direct power of excess landholders, based on their holdings and their votes, is distributed very unequally within the several water districts on Kings River. In Fresno, the most populous irrigation district, only about 13 per cent of all lands are held in tracts of above 160 acres in size, and only about 6 per cent above 320 acres. The district consists of about 240,000 acres, and, in 1944 , there were 12,400 landowners. ${ }^{152}$ Since

148 "My recent trip in the Kings River area convinced une that there is a growing number of land owners who, having observed just this summer the benefits derived or to be derived by those who have contracted for Friant-Kern water, are now ready to enter into similar contracts for Pine Flat water. Several irrigators with whoin I spoke stated that they are getting fed up with KRWA, feel that organization is asking them-the smaller and majority of farmers in the area-to pull chestnuts out of the fire for the big boys, and actually seek advice on how they can break away and contract with the Bureau." Letter from Arthur A. Maass to Joel Wolfsohn, October 28, 1951, reproduced in Excess LaNd Provisions, op. cit. suppo note 138, pt. 1, app. $32: 1$.

119 Lindsay-Strathmore Water District. The other district was South San Joaquin Municipal Utility District. Contracts covered water service, distribution system, or were supplementary or amendatory. Bureau of Reclamation Regional Office (Sacramento), California Elections on Reclamation Water Contracts (April, 1952), on file in Sacramento regional office.

100 Ivanhoe, Iindmore, Orange Cove. Ibid.

161 Exeter, Limdsay-Strathinore, Stone Corral, Terra Bclla, and Tulare. Three districts (Delano-Earlimart, Lower Tule, Saucelito) signed in 1951 approving by a combined vote of 750 to 49 . Porterville approved by 58 to 42 , but failed to give the necessary two-thirds majority until the following year. In 1952, five districts (Delano-Earlimart, Ivanhoe, Limdmore, LindsayStrathmore, and Porterville) approved contracts by a vote of 744 to 125 . Saucehto rejected a supplementary, or amendatory, contract by a vote of 33 to 45 . Ibid.

152 Computations made from data in letter from C. Sain Johnson, assessor-collector, Fresno Irrigation District, to Charles L. Kaupke, May 20, 1944, reproduced in Hearings on H.R. 3024 Before a Subcommittee of the Senate Committee on Appropriations, 79th Cong., 1st Sess, 1001-03 (1946), and testimony of Charles I Kaupke, Hearings on S. 912 Before a 
all electors vote in irrigation districts, the power of excess landowners, except as they influence others, is meager.

At the other extreme from Fresno is the least populous district on Kings River, the virtually uninhabited Tulare Lake Basin Water Storage District. The district consists of 192,000 acres. Around 90 percent of all its lands, or approximately 270 square miles, is in holdings in excess of 160 acres. ${ }^{153}$ Votes are cast, not by polling the electors, of whom there are few if any, but by counting votes reckoned in units of $\$ 100$ of assessed valuation. Manifestly the power of excess landowners to guide the actions of Fresno or other irrigation districts is far less direct and sure than their power to guide the actions of Tulare Lake Basin Water Storage District in which they hold the power directly.

Since 1946 the KRWA had engaged in correspondence and negotiations directed toward conclusion of a contract on terms satisfactory to its leadership, i.e., excluding the excess land provision. ${ }^{154}$ This procedure was initially successful, but the usefulness of the KRWA in preventing acceptance of contracts by individual districts having power to make them was limited by the fact that it could not offer to serve the districts as an alternative contracting agency. It lacked legal powers required to support the financial obligations assumed in contracts. In this situation the KRWA sought a more effective instrument to prevent individual districts from concluding contracts complying with the excess land law, and thus breaking the solid front of resistance. The means the association chose was a new district on Kings River with legal power to contract with the United States. A bill was prepared for submission to the State legislature to create the Kings River Conservation District, including within it the lands of previously existing districts, yet without extinguishing the districts themselves or diminishing their legal powers. Individual districts already had the power to contract, but the new district offered a unified and legally qualified alternative. ${ }^{155}$

153 Letter from Commissioner of the Bureau of Reclamation Michael W. Straus to Senator Douglas, Feb. 2, 1949, copy on file in Bancroft Library, University of California, Berkeley.

154 EXcess LaNd Provisions, op. cit. supra note 138, pt. 2, exhibits 1-4.

155 "The KRWA is in a sense an extra-legal organization which repesents all of the irrigation districts in the Kings River water service area. All of the districts have given the Association power of attorney to negotiate for them on Pine Flat. It is this power of attorney that many of the irrigators and some of the irrigation district directors want to recapture so they can negotiate directly with the Bureau for a regular contract. At the last session of the Catifornia legislature a bill was passed to establish a singie irrigation district for the entire Kings River area. (In effect, giving legal status to the KRWA.) I was unable to obtain definite evidence, but believe that this bill was pushed through by KRWA supporters to prevent the imminent possibility of one or more of the existing districts breaking away from the Association and signing a regular contract with the Bureau. If one were to break away, the Association's solid front would thus be pierced, and its effectiveness, badly darnaged." Letter from Arthur Maass to Joel Wolfsohn, Oct. 28, 1951, reproduced in Excess LaND Provisions, op. cit. supra note 138, 
Press and other available reports do not yield indications that this explanation for creating KRCD was ever offered generally to the water users of Kings River area. The customary procedure of forming irrigation or other water districts by vote of electors or landowners was avoided in forming the Kings River Conservation District, and the proposal to estabhish the KRCD was taken directly to the State legislature.

Local Kings River press furnishes a front-page account of how the KRWA described and presented its KRCD Bill to a small community within the project area. Three speakers addressed the meeting. According to the local account the first speaker, who was sponsor of the bill in the legislature, told the people that above all, KRCD would keep control of the Kings River water in the hands of the people. ${ }^{156}$ The second speaker, described as "a Fresno attorney who helped draw up the bill," but unnamed, stated that "until recent dates no one contested the rights of the water users but with the advent of the federal government into the picure in California we find it necessary to set up a legal entity." 157 The local account gives no indication that he gave a reason for the necessity. Existing districts were legal entities with powers to contract to obtain water, and were not to be abolished.

The Kings River water master told the ineeting, "I hope we can run our affairs so that we never lose control of our water rights.' . . . 'This country is becoming socialized faster than you think,' [and] that if the federal government can get control of the water, together with the power rights on our rivers, they (the bureaucrats) can control just about any kind of an economy they want."158

The local reporter, remarking that "we [newspaper writers] don't know much about this water business," said he grasped one idea from the meeting that appeared to furnish solid foundation: "To our mind one of the biggest features of the [KRCD] plan is the retaining of control by the people."159 Apparently no mention of the excess land law was made to the meeting, and no question raised whether, in the phrases "control of our

156 Assemblyman William Hansen, sponsor of Cal. Assembly Bill 340, Reg. Sess. (1951), as reported in Cutler-Orosi Courier (Orosi, Cal.), Aug. 23, 1951, p. 1, col. 2.

157 Id. at p. 1 , cols. 3,4 .

108 Charles I. Kaupke, quoted ibid. Two months later the quartermaster-adjutant of the Cahifornia Department, Veterans of Foreign Wars, replying to this argument of the KRWA, said: "Do not be misled by the endless repetition of spoksemen on Kings River that the Bureal of Reclamation is going to deprive any water users of their water rights. There is purpose behind the repetition, but the statement, on the face of it is false. Reclamation law specifically requires the Bureau to respect those water rights, and the courts of the United States are open to anybody who thimks his rights are not being protected as required by law." Statement of M. C. Hermann before a subcommittee of the House Public Lands Committee, at Sacramento, Cal., Dec. 19, 1950, in 97 Cong. Rec. 13, 14 (1951).

150 Cutler-Orosi Courier, (Orosi, Cal.), Aug. 23, 1951, p. 1, col. 7 . 
water rights" and "control by the people," a distinction between individuals owning more, and those owning less than 160 acres of land, might be important.

The presentation by the KRWA to the State legislature of the necessity for creating a new district apparently was consistent with that made to the meeting at Reedley, and not much more illuminating. The bill recited that the legislature "finds and determines" that formation of an overall district will benefit "the lands thereof," and that "it is necessary to have a political entity embracing the areas having rights to said waters created in order to protect such rights. ..." 160 Neither the necessity, nor the "benefit" to "the lands" were clarified further in the bill, nor apparently otherwise. The water master for the KRWA told the Assembly Committee on Conservation, Planning and Public Works at a lengthy hearing that "the issue lias nothing to do with the 160 -acre limitation." His reasoning was that "the same contract would be signed, whether by one district or its many components." 101

The day after the hearing, an editorial in the San Francisco News said:

Ordinarily irrigation and water districts are formed by vote of the landowners of the proposed district, a democratic process that has prevailed from the very inception of the district plan of utility development. . . . Why has this unusual procedure been resorted to? Some residents of the area believe it is intended to drive a wedge into the heart of the Central Valley Project thereby preventing the CVP from being, as originally imtended, an integrated, compreliensive water plan for the whole interior basin of the state. ... [W] see no reason for departing from the timehonored custom of letting landowners vote on formation of water districts. The Legislature should be sure it knows what the real purpose and effect of this proposal is before voting finally upon it. ${ }^{102}$

The legislature created the Kings River Conservation District that, before long, superseded the KRWA in negotiating with the Bureau of

160 Cal. Assembly Bill 340, Reg. Sess. (1951).

161 Sacramento dispatch: "Kings River Water District Action Delayed," San Francisco News, March 29, 1951, p.9, col. 1. "Charles Kaupke, water master of the Kings River Water Association, told the committee the members of his association-including irrigation districts, storage districts, mutual water companies and individual farmers-want the district because they want a single legal entity to contract with the Federal Government for water contracts when Pine Flat Dain is completed in 1953. . . Counmittee rnembers queried why local residents couldn't vote on forming the district, before the Legislature okehed [sic] it. Wallace D. Henderson (D., Fresno) urged that this step be tried. Harlan Hagan [sic] (D., Hanford) protested that land owners who are not water users are getting blanketed into the district without say-so. O. M. Davis, a Kerman rancher, declared that the bill in effect represents a plot by the Kings River Water Association and the Pacific Gas and Electric Co. to prevent this area from becoming a part of Central Valley. Assemblyman Hansen hit back at Mr. Davis as a disgruntled campaign opponent of two years back."

162 San Francisco News, March 30, 1951, p. 20, col. 2. 
Reclamation. Changes in personnel in the positions of leadership were few as between KRWA and KRCD, policies remained the same, and resistance to the excess land law was more solid than before. ${ }^{103}$

The KRCD picked up where the KRWA had left off. On September 10, 1952 , the KRCD rejected draft number four of the proposed repayment contract on the ground that it was "based upon principles which are not acceptable to the owners of water rights in the Kings River Service Area." The principle "acceptable" to the board of directors of KRCD was an "understanding" that "lump sum payment ... would entitle the Kings River water users to all the storage space in the Pine Flat Reservoir, subject only to flood control operations by the army engineers; and that the Bureau of Reclamation, in consideration of such payment, would no longer claim that the project was in any manner subject to reclamation laws." "164

During the next 6 weeks, negotiations took a fresh turn. The District Manager of the Bureau of Reclamation threatened, in face of rebuff by the KRCD, to undertake negotiations with individual districts. At the same time he offered to accept lump sum payment and to agree that this would "remove" the excess land law. ${ }^{165} \mathrm{He}$ added: "[W] have gained the impression that this assurance opened the way to completing the contract." 165a The general election of 1952, which followed closely, produced a change of administration, and negotiations were ended for more than a year.

Secretary of the Interior Douglas McKay resuned negotiations with KRCD on November 9,1953, offering that advance lump sum payment would render the excess land laws "inoperative." His successor, Secretary Seaton, rejected the contract on July 12, 1957, offering a slightly different interpretation of the law. ${ }^{106}$ Secretary McKay would have permitted individual landowners to avoid the law by completing their payments; Secretary Seaton was willing to permit only districts to do this. ${ }^{167}$

163 Elections to directorships of water districts are held separately at odd times, and attendance of more than $10 \%$ of persons eligible to vote is extraordinary. The turnout of voters for the KRCD election was somewhat larger than usual, but very small measured by the turnout at general elections.

104 Letter from Philip A. Gordon, president, board of directors, Kings River Conservation District, to Jack W. Rodner, District Manager, Bureau of Reclamation, Sept. 10, 1952, reproduced in Excess LaND Provisions, op. cit. supra note 138, pt. 2, exhibit 26:1. The second Werdel bill (H.R. 413, 82d Cong., 1st Sess. (1951)), validating this "understanding," had failed of passage in the then current Congress.

105 Letter from Jack W. Rodner to Kings River Conservation District, Oct. 21, 1952, reproduced in Excess LAND Provistons, op. cit. supra note 138, pt. 2, exhibit 27:2, :3. Before leaving office, Secretary of the Interior Chapman rejected lump sum payment on Kings River. See Taylor, Excess Land Law: Execution of a Public Policy, 64 Yare L.J. 477, 506-09 (1955).

$105 a$ Ibid.

106 Letter from Secretary of the Interior Seaton to Philip A. Gordon, July 12, 1957, copy on file in Bancroft Library, University of California, Berkeley. 
Secretary McKay's willingness to render the excess land law "inoperative" by completion of money payments eliminated the resistance of excess landholding interests on Kings River and Tulare Lake project to conclusion of a contract by the KRCD with the Bureau of Reclamation. Secretary Seaton's interpretation rendered the Kings River Conservation District not only useless to thein, but an obstacle.

The problem of getting non-excess landholders to join with excess landholders in prepayment, for the purpose of helping the latter at a substantial and unnecessary cost to the former-since reclamation law charges no interest on deferred payments-liad been a concern of excess landholders since at least 1951. Secretary McKay had dissolved the problem entirely by offering to accept payments by individual excess landholders under a single contract with KRCD which would not require any non-excess landowners to pay cash to help excess landowners avoid the law. Secretary Seaton restored the problein, in part, by agreeing to accept district payments only. This would require some non-excess landowners to advance cash, if the excess landholders of the district were to escape the law.

The response of KRWA to Secretary Seaton's offer was to resume its role as spokesman for Kings River and Tulare Lake interests, to lay aside its creature, the Kings River Conservation District, and to prepare for the previously avoided individual district contracts.

On May 19, 1959, the attorney and secretary for the KRWA announced that the new contract " "would allow water agencies to sign individually." " He said that " 'some of the water agencies will want a 40-year interest-free payment contract, and others will want a lump sum payment contract.' " Upon completion of payments the districts " would not be bound by the water delivery limitation.' "While contracts would be signed by individual districts, the KRWA secretary said, " if it goes through I expect all the agencies will sign at the same time." "168 Two weeks later news reports said that regional officials of the Bureau of Reclamation in Sacramento were "optimistic over chances of top level approval" of the contracts in Washington. ${ }^{169}$

The probable reason why KRWA preferred individual district contracts to an overall $\mathrm{KRCD}$ contract is not far to seek. Under the terms approved by Secretary Seaton, about 127 owners of excess lands in Tulare Lake Basm Water Storage District could easily obtain a prepayment contract. If necessary, they could outvote about: 635 owners of non-excess lands, on the voting basis of $\$ 100$-units of assessed valuation. ${ }^{170}$ By so

168 Fresno Bee, May 20, 1959, p. 12-A, col. 1.

169 Fresno Bee, June 8, 1959, p. 7-A, col. 1.

${ }^{170}$ Statement of M. C. Hermann, quartermaster-adjutant, Department of California, Veterans of Foreign Wars, read into the record by California Congressman John F. Shelley, 97 Cong. Rec. 6351-52 (1951). 
doing they could render the excess land law inoperative at a stroke on about two-thirds of all the excess lands of the project area.

\section{V \\ PROCESS}

When one faces up to the policy and collects any and all statements and pronouncements on the principle of the 160-acre law, one is impressed by the unanimity of support for it from Members of Congress and representatives of the executive establishment. Witness the statements by all members of this committee during this session today. In the light of this support for the principle of the small farm and the 160-acre law, efforts to escape the provision should have rough going in our Federal Government.-Arthur A. Maass, $1958^{171}$

Senator Kuchel, I think in this very room you have people who in the main must be satisfied and in agreement before any real progress can be made on the San Luis project. There is one segment of opinion represented by the State Grange, Mr. Sehlmeyer, who is a very admirable man, who does not endorse any type of State project because the State does not have an acreage limitation law.... However, I think agreement could be achieved without the agreement of $M r$. Sehlmeyer, and I think it has to be achieved ... regardless of whether this Congress passes an authorization bill or not, because... the State has so many locks on various aspects of progress that the State acceptance has to be present for any progress to be made.-Congressman Harlan Hagen, $1958^{172}$

Procedure for arriving at public decisions may determine the decision itself. The balance of interest against principle may be controlled by procedure. The excess land law, representing the principle of wide distribution of resources and control of unjust enrichment, suffers damage continuously from faulty procedure.

The principal means by which the pressure of interests works against principle and policy, as represented by the excess land law, is simple and effective. The common method, as Dr. Arthur Maass of Harvard University testified to the Senate Irrigation and Reclamation Subcommittee, is "specifically by not facing up to the issue directly in the light of full public discussion and debate."173 Among the examples cited by Dr. Maass were (1) "proposals to avoid the limitation entirely by lump-sum payout" which "should be widely discussed for what they are and not considered as a

171 Testimony of Arthur A. Maass, Hearings on S.1425, S. 2541, and S.3448 Before the Subcommittee on Irrigation and Reclamation of the Senate Conmittee on Interior and Insular Affairs, 85th Cong., 2d Sess. 91 (1958) [hereinafter cited as 1958 Hearing on S.1425, S.2541 E S.3448.]

${ }_{172}$ Testimony of Congressman Harlan Hagen, Hearings on S.1887 Before the Subcommittee on Irrigation and Reclamation of the Senate Conmittee on Interior and Insular Affairs, 85th Cong., 2d Sess. 42 (1958) [hereinafter cited as 1958 Hearings on S.1887].

173 Testimony of Arthur A. Maass, 1958 Hearings on S.1425, S. 2541 \& S.3448, at 90. 
technical matter of contract ...;" (2) "partnership bills" in which "public and congressional discussion" have not "focused public attention on the ... quite intentional result . . . to repeal, exempt, or modify the 160 -acre law;" (3) the proposed two-price system for water, because it offers too much "opportunity for deception;" and (4) the proposal to allow administrators "greater flexibility," because an administrator needs "desperately a firm and unequivocal statute close up behind him" as protection from the "tremendous pressures on administrative agencies."174

The legislature carries two related but separable functions: (1) to declare the principle or standard by which private pressures can be limited or curbed in the public interest, and (2) to strike a balance among the pressures of interests. In preparation and consicleration of the San Luis bill $^{175}$ the two functions became confused; procedure appropriate to the balancing of pressures was employed where principle was at stake. The chairman of the Senate committee on the bill, faced by diverse interests and opposed views on principle, admonished those who came before him: "First of all, you ought to be able to agree between yourselves voluntarily. If you cannot do that I do not think you ought to go further with it then."170

The chairman's admonition was heeded, and an agreement produced. Agreement was achieved, however, by excluding those groups, such as the California Grange and Labor Federation, that stood solid for principle. Congressman Harlan Hagen described how, and among whom, agreement was reached:

This compromise was the binding agreement of a representative of California's Governor, the two California Senators, Congressman Sisk, and myself, and representatives of San Luis, Kern County, and Los Angeles water interests, arrived at in a March 13 meeting attended by representatives of the Bureau of Reclamation. ${ }^{177}$

The price of agreement, predetermined by the procedure that included some and excluded others, was sacrifice of principle. Not complete sacrifice,

$174 I d$. at $89-92$. The author has analyzed the process elsewhere in a detailed description that need not be repeated. See Taylor, Excess Land Law: Legislative Erosion of Public Policy, 30 ROCKY MT. L. REv. 1 (1958).

175 See supra, text at note 23 .

176 Remarks of Senator Clinton P. Anderson, 1958 Hearings on S.1887, at 172.

177 Testimony of Congressman Harlan Hagen, Hearings on S. 44 Before the Stubcomntittee on Irrigation and Reclamation of the Senate Commitlee on Interior and Insular Affairs, 86th Cong., 1st Sess. 29 (1959). Governor Brown claimed a share in the agreement: "For the first time in these long discussions ... . Californians come before you united, offering a single plan with unanimous support. In conferences during the past 2 weeks, representatives of the Westlands Water District, the Metropolitan Water District of Southern Cahifornia, and Los Angeles Department of Water and Power, the State Farm Bureau Yrederation, and Kern County interests have worked with my administration and the authors of this legislation to remove potential sources of conflict. The bill before you reflects the minor amendments to which all concerued have agreed." H.R. Rep. No. 399, 86th Cong., 1st Sess. (to accompany H.R. 7155) 7 (1959). 
however, for the agreement included an estimate by the interests sharing responsibility for its making, of the concessions to principle that were necessary to secure passage of the bill if opposed in Congress by friends of the excess land law. The estimate proved erroneous, at least in the Senate, which refused to exempt San Luis project from reclamation law in early May.

The Interior and Insular Affairs Committee of the House of Representatives faced the same issue on May 29, 1959. The majority insisted on retaining the specific exemption from reclamation law in the House bill (H.R. 7155, section 7) that Senators Douglas and Morse had removed from the Senate bill (S. 44, section 6(a)).$^{178} \mathrm{It}$ argued that its retention would "contribute to clarity and advance construction of the projects." In doing so, it relied on the procedure that produced agreement among interests by excluding those who would disagree on grounds of principle. ${ }^{179}$

The House report tried to widen another door of escape. This was the administrative order of Secretary Seaton that could free the State from compliance with the excess land law by prepayment. ${ }^{180}$ The report appropriately might have asked Congress to validate this administrative interpretation, as Congressman Werdel had done in the 81st and 82d Congresses, unsuccessfully. ${ }^{181}$ Instead, it said no legislation was "pending" before

178 See supra, text at note 64 .

179 The report said that preparation of the bill "involved bringing together . . . many diverse interests and points of view," and for this reason the author "should be given considerable latitude in the way he expresses the position that is arrived at. ..." This resembles the explanation given for retaining the exemption in the Senate, viz., that "the people affected want this additional assurance." H.R. REP. No. 399, 86th Cong., 1st Sess. (to accompany H.R. 7155) 15-16 (1959) ; 105 Cong. Rec. 6738 (daily ed. May 5, 1959).

180Like the Secretary, the majority of the committee rests its view finally on an administrative ground, rather than on statute; it says the administrative order "is now so well fortified by history that it can probably be successfully attacked by no one except Congress. H.R. REP. No. 399, supra note 179, at 14. Secretary Seaton's Solicitor argued that no court had declared the doctrine invalid; the committee majority conceded that the doctrine had "not been construed in any reported judicial decision." Ibid. The House report omits mention of documented analyses that arrive at a conclusion contrary to that of Secretary Seaton and itself. See, e.g., correspondence between Senator Douglas and Secretary of the Interior Seaton, reproduced in 1958 Hearings on S. 1425, S. 2541, \& S.3448, at 20-25; H.R. REP. No. 399, 86th Cong., 1st Sess. 11-16 (1959); Taylor, The Excess Land Law: Execution of a Public Policy, 64 Yasx. L.J. 477 (1955).

181 H.R. 7915, 81st Cong., 2d Sess. (1950) ; H.R. 413, 82d Cong., 1st Sess. (1951). The House report and the California Labor Federation, opposed in their views toward the excess land provision, unite in recognition of the concert of tactics in Congress, State legislature and Interior Department, and in the dominating influence of the agreement among "many diverse interests and points of view." H.R. REP. No. 399, 86th Cong., 1st Sess. 15, 16 (1959). The Federation, in a reference to a "three-pronged attack" manifested in the San Luis bills, Seaton interpretation, and California State water program legislation, stated: "These three drives are not necessarily coordinated, but, significantly, each of them would serve the same end: monopolization of irrigation water furnished by public monies .... We appreciate the fact that some of those supporting H.R. 7155 have accepted the questionable language as the price they must 
Congress or "ever" had been introduced to "overrule the departmental interpretation."

The House report added no substantial support either to the defense of the exemption by Senators Kuchel and Engle, or to the defense of Secretary Seaton's proposed action on Kings River. The majority of the House committee could not change existing law by expressing an opinion; and it refrained from asking Congress for statutory authority. Instead it encouraged Secretary Seaton to proceed in his offer permitting excess landholders on Kings River, and elsewhere, to avoid the excess land law. ${ }^{182}$

The arenas in which public decisions are made in America are informal and formal, and they are numerous. Legislatures, courts, and the offices of administrators are not sequestered, but exposed in varying degrees to winds as diverse as those bearing the results of agreements among interests, and those carrying the score in straw polls on questions of principle. ${ }^{183}$ They are not open equally to winds from all quarters except as public discussion and debate is assisted, rather than avoided.

The principle of equitable and wide distribution of benefits and resources is simple, but legal language and the details of projects invest it with an appearance of complexity. In this obscurity, principle can fail to receive necessary consideration in congressional channels where it passes in review. Senator Morse asserted this was true of the San Luis exemption: "The sad fact is that I believe the Senate Committee on Interior and Insular Affairs never gave consideration to the points... which the Senator from Illinois . . . has brought out so eloquently on the floor of the Senate."184

pay to gain support from certain interests in California. We do not doubt the sincerity of these men, but we cannot accept their assurances, and we do not believe that the whole framework of future California water development should be lashed to their political counmitunents." Cabifornia Labor Federation, Statement on Water Issues 1, 4 (ca. July 15, 1959), copy on file Bancroft Library, University of California, Berkeley (mimeo).

${ }^{182}$ Senator Engle earlier took the position of advising "'river officials to sign a contract with the government and pay off the cost of the project within ten years. Then the 160 acre limitation will not apply.'" Fresno Bee, Feb. 12, 1959, p. 1, col. 3.

183 As aftermath of the legislative proceedings in the shadow of the agreement among interests, the San Francisco News reported the opinion of a party leader: "The Governor, at the budget session next winter, must inake good on his promise that there'll he no 'unjust enrichment' to large landholders from the water program. If he gets that, lie can go all the way. If lie doesn't, he'll be just another politician." San Francisco News, June 18, 1959, p. 6, col. 3. See also San Francisco Chromicle, June 21, 1959, p. 1, col.2, and p. 18, col. 5; id., July 5, 1959, $\S 2$, p. 6, col.5. The Chronicle, conducting a straw poll on water developinent, reported that $58.9 \%$ of those polled on the question "Should the 160-acre limitation apply to irrigation water ?" answered yes, and $21.5 \%$ answered no. Id., June 29, 1959, p. 32 .

184105 Cong. REc. 7074 (daily ed. May 11, 1959). Senator Douglas said: "The owners of big estates cannot get what they want by Senate action alone ... and they think they can como to Washington, with no one greatly concerned over the issue and push their proposal through Congress on favorable terms to themselves." 105 Cong. REc. 6738 (daily ed. May 5, 1959). See also Taylor, The Excess Land Law: Legislative Erosion of a Public Policy, 30 Rocky MT. L. Rev. 1, 13 (1958). 
Pressure against principle produces curiously incongruous political behavior. A Congressinan authors a bill proposing partnership between the federal government and a State, and containing an exemption from the excess land law. A governor approves the partnership bill, including the exemption. The Congressman, while sponsoring the federal exemption, wires State legislators urging them to adopt State "safeguards" using the "federal limitation" as a "pattern," and explaining that "had the State enacted such limitations" his task as Congressman "would have been immeasurably assisted." 185 The governor blocks efforts in his legislature to enact the safeguards the Congressman urges, ${ }^{186}$ and proposes action later to prevent "any unjust enrichment or monopolization of benefits by large landholdings as a result of either Federal or State operation." 187 CongressInan and governor, in office on a party platform approving the federal excess land law, support an executive mterpretation that would reduce it to a mere shadow.

The issue is not one of the sincerity of public men in their professions of devotion to principle. Devotion to principle becomes impossible or ineffective when pressures rule and responsible organs of government allow confusion of issues, rather than assist their clarification in the arenas of public discussion and debate.

Public principles and policy are forged in these arenas and in them alone can public principles be maintained against pressures that flourish on silence and confusion. Defeat of the exemption by the Senate was a demonstration.

There zere only a few people who listened to the debates. . . Yet the extraordinary thing is that as the facts were developed one could see the opinion of the Senate change... The analysis of the bill spread by a process of osmosis through the Senate as a whole, so that those who did not hear the debates nevertheless read the RECORD, or colleagues upon whom they relied relayed information to them.... There has been too much of an idea, Mr. President, that important public matters should be settled off the floor, should be settled by secret arrangements, and that debate itself should be minimized and curtailed, being at best useless and at worst actually harmful. I hope our experience in this debate will encourage other Senators from time to time, when they feel strongly about a measure and feel informed about that measure, to take the floor of the Senate and to express their convictions honestly and accurately. ${ }^{188}$ _Senator Paul Douglas, 1959

185 Congressman B. F. Sisk, quoted in Valley Labor Citizen (Fresno), July 3, 1959, p.6, col. 2 .

186 California Labor Federation, Weekly Newsletter, June 26, 1959, p. 7, col. 3.

187 Letter from Edmund G. (Pat) Brown to Senator Engle, May 7, 1959, reproduced in H.R. REP. No. 399, 86th Cong., 1st Sess. 15 (1959).

188105 CoNG. REc. 7175 (daily ed. May 12, 1959). 